University of Wollongong

Research Online

Faculty of Business - Papers (Archive)

Faculty of Business and Law

2013

Mutual fund ownership, firm specific information, and firm performance: evidence from China

Wenhua Sharpe

Deakin University

Gary Tian

University of Wollongong, gtian@uow.edu.au

Hong Feng Zhang

Deakin University

Follow this and additional works at: https://ro.uow.edu.au/buspapers

Part of the Business Commons

Research Online is the open access institutional repository for the University of Wollongong. For further information contact the UOW Library: research-pubs@uow.edu.au 


\title{
Mutual fund ownership, firm specific information, and firm performance: evidence from China
}

\begin{abstract}
This paper shows empirically that the positive association between mutual fund ownership and firm value in China is mainly driven by the informed trading of mutual funds. Utilizing the unique short term feature of mutual fund holdings for the period from 2001 to 2010, we provide an informational link between a decomposed component of market-to-book ratio (firm specific valuation component) and mutual fund holdings. Specifically, we find that firms with a higher level of mutual fund ownership are associated with a higher specific value. Moreover, the positive association between the specific value of a firm and mutual fund ownership is more pronounced in firms with a higher level of specific information (or higher idiosyncratic volatility). We argue that in an emerging market such as China, mutual funds help to improve market efficiency by incorporating private information into stock prices through their informed trading although they are really a lack of incentive to monitor management.
\end{abstract}

\section{Keywords}

fund, firm, specific, ownership, information, mutual, performance, evidence, china

Disciplines

Business

\section{Publication Details}

Sharpe, W., Tian, G. \& Zhang, H. (2013). Mutual fund ownership, firm specific information, and firm performance: evidence from China. China International Conference in Finance (pp. 1-42). CCFR. 


\title{
Mutual Fund Ownership, Firm Specific Information, and Firm Performance: Evidence from China
}

\author{
Wenhua Sharpe ${ }^{1}$, Gary Tian ${ }^{2}$ and Hong Feng Zhang ${ }^{3}$
}

November 2012

\begin{abstract}
This paper shows empirically that the positive association between mutual fund ownership and firm value in China is mainly driven by the informed trading of mutual funds. Utilizing the unique short term feature of mutual fund holdings for the period from 2001 to 2010, we provide an informational link between a decomposed component of market-to-book ratio (firm specific valuation component) and mutual fund holdings. Specifically, we find that firms with a higher level of mutual fund ownership are associated with a higher specific value. Moreover, the positive association between the specific value of a firm and mutual fund ownership is more pronounced in firms with a higher level of specific information (or higher idiosyncratic volatility). We argue that in an emerging market such as China, mutual funds help to improve market efficiency by incorporating private information into stock prices through their informed trading although they are really a lack of incentive to monitor management.
\end{abstract}

JEL classification: G14; G23; G32

Keywords: Firm performance; Mutual fund ownership; Idiosyncratic volatility

\footnotetext{
${ }^{1}$ School of Accounting, Economics and Finance, Deakin University, Australia. Email: wsharpe@deakin.edu.au.

${ }^{2}$ Gary Tian, Professor of Finance, School of Accounting and Finance, University of Wollongong, Australia.

Email: gtian@uow.edu.au.

${ }^{3}$ Corresponding author. Hong Feng Zhang, School of Accounting, Economics and Finance, Deakin University, Australia. Email hong.zhong@deakin.edu.au.
} 


\section{Introduction}

It has been widely recognized in the literature that institutional ownership is positively associated with stock prices or firm value (Gompers and Metrick 2001; Ferreira, and Matos, 2008; Aggarwal, Erel, Ferreira, and Matos, 2011; among others). One strand of the studies contributes this positive association to a monitoring role (monitoring hypothesis) played by institutional investors who influence executive compensation structures (Hartzell and Starks, 2003), while the other strand of studies argues that the presence of institutional investors enhances the informativeness of stock prices (informational hypothesis) by incorporating their private information through trading activities (Sias, Starks, and Titman, 2006; Ferreira and Lux 2007). However, to empirically differentiate the monitoring effect of institutional ownership on stock performance from the informational effect is challenging.

Recently Yan and Zhang (2009) further document that short term institutional investors (with a high portfolio turnover rate) have clear informational advantage over long term institutions (with a low portfolio turnover rate). They find that the positive relationship between mutual fund ownership and future stock returns documented by Gompers and Metrick (2001) is driven by short term institutions. Nevertheless, there is still no direct evidence on: How the informative trading of short term institutions affects firm performance, in other words, what is the channel through which the presence of short term institutions enhances firm performance? How can the monitoring effect of institutional ownership on stock performance be isolated from the informational effect? Furthermore, using the stock portfolio turnover rate of an institution as a proxy for its duration of ownership in previous studies (e.g. Yan and Zhang 2009) is not without controversy because the high portfolio turnover rate of an institutional holder does not necessarily mean it holds stocks for a short 
term. This paper investigates how mutual fund ownership is associated with firm specific valuation and how mutual funds help the incorporation of firm specific information into firm value by utilizing a unique institutional feature in the Chinese stock market, the short termism of mutual fund holding.

China's stock markets have been dominated by individual investors and short term institutions since they were established in the 1990s, and this unique feature has not been changed, even after the introduction of large institutional investors through the establishment of closed and open- end mutual funds in 2001. For big institutional investors in China such as mutual funds, QFIIs, and Social Security funds, the holding duration of over $60 \%$ of their investments is less than 3 months, and only around 5\% of the holdings are longer than 12 months (China Capital Markets Development Report, 2008) ${ }^{4}$. Given this extremely short investment horizon, it is very hard for the mutual funds in China to have sufficient incentives to monitor the management of their holding firms. However, this short termism feature of mutual fund holding provides us with a unique environment for testing the economic effect of mutual fund ownership on firm performance or firm value, and it also allows us to distinguish the monitoring hypothesis from the informational hypothesis for the economic association between mutual fund ownership and firm value in China. In addition, investors will face strict requirements for disclosure from the China Securities Regulatory Commission (the CSRC) once their holding shares have reached the 5\% threshold of a listed firm. It is rare for mutual funds to hold more than $5 \%$ of stocks of a particular listed firm whereas it is common for an

\footnotetext{
${ }^{4}$ According to Figure 3.23 in China Capital Markets Development Report (2008), the average turnover ratio (927\% in Shanghai Stock Exchange and 987\% in Shenzhen Stock Exchange) in Chinese stock markets is seven times higher than that (around 129\%, refer to the text for details) in the U.S. markets. Huang, Sialm and Zhang (2011) report an average turnover ratio of $89.52 \%$ for the mutual funds in the U.S. over the period between 1980 and 2009. Tang, Wang and Xu (2012) report an average fund turnover rate of $316.71 \%$ between 2004 and 2010. Even in the top quintile of their sample, the average turnover of $186.35 \%$, around twice of that in the U.S.
} 
institutional investor in the U.S. to hold more than 5\% of a firm's stock. For example, from $41 \%$ to $73 \%$ of the firms sampled by Chen, Harford, and Li (2007) have at least one institutional block holder (holding $5 \%$ or above). This holding preference by Chinese mutual funds will further discourage them from implementing a monitory role. We argue that the positive association between firm value and mutual fund ownership is more likely to be explained by the informational hypothesis rather than the monitoring hypothesis, since mutual funds can simply gather and trade on their clear informational advantage and expertise over individual investors.

Using mutual fund ownership data from 2001 to 2010, we first confirm that mutual fund ownership is positively and statistically associated with both firm value (proxies by market-to-book ratio) and firm operating performance. However, it is possible that mutual fund holding could indirectly affect firm value through its influence on the firms' operations. In other words, we cannot rule out the possibility that mutual funds sell their stocks rather than exert any effort to influence management, even if they do not have sufficient incentive to directly monitor management due to a short holding horizon and a small stake in the firms. Furthermore, firm value and firm operating performance are correlated because firm value reflects both the current and future information of a firm, but the operating performance is correlated more with the firm's current information. To successfully test whether the valuation link from mutual fund ownership to informed trading and firm value exists, it is necessary to isolate the valuation component that is driven by operating performance from the component that is correlated with firm specific information.

Following a decomposition methodology developed in Rhodes-Kropf, Robinson, and Viswanathan (RKRV) (2005) and advocated by Hertzel and Li (2010), we decompose firm value (MTB ratios) into a component related to operating performance (LRVTB), a 
component of misevaluation or firm specific error (FSE) and a growth option component (TSSE). We find that all three valuation components are positively and statistically associated with mutual fund ownership. A regression on the firm specific component (FSE) has the largest coefficients on mutual ownership, which strongly supports our proposed association between firm specific value and fund ownership. We then test the interaction between mutual fund ownership and firm specific information (idiosyncratic volatility) and how the interaction affects firm specific error (FSE). The empirical evidence confirms our informational hypothesis that mutual fund ownership is positively associated with firm specific valuation component by an increase in the informativeness of stock prices or idiosyncratic volatility. And the positive association between firm value and mutual fund ownership is likely due to informed trading and price discovery by mutual funds in China.

To alleviate any concerns about the robustness of our findings, we use alternative measures for mutual fund holdings, a change-in-change approach, and a quasi-natural experiment to verify the results. We first use an alternative measure for informed trading by mutual funds as advocated in Sias, Starks, and Titman (2006), and a change in the number of mutual funds holding a stock to replace the fraction of holding measure. We then run a change-in-change approach and regress changes in firm specific value on changes in mutual fund holdings to address any concerns of endogeneity caused by reverse causality. Last, we use a quasi-natural experimental approach to see how the association between firm specific value, and idiosyncratic volatility and mutual ownership responds to the Split Share Structure Reform that happened in China from 2005 to 2007. We find that our informational argument is robust to the alternative holding measure, the alternative empirical approach, and the quasiexogenous event. 
Our paper complements the mutual fund ownership literature in the following two ways. First, we use the short term holding pattern widely observed in the Chinese mutual fund industry to disentangle the informational hypothesis from the monitoring hypothesis for the economic effect of mutual fund ownership on firm value. Our empirical evidence suggests that in an emerging market such as China, mutual funds might lack incentives to monitor management, but they could help to improve market efficiency by incorporating private information into stock prices through their informed trading. Second, we provide a valuation channel for mutual fund ownership to be associated with firm value through its positive association with idiosyncratic volatility.

The remainder of this paper is organized as follows. Section 2 develops testable hypotheses and presents the decomposition methodology of market-to-book ratios. Section 3 describes the data and presents descriptive statistics. Section 4 examines the association between mutual fund ownership and firm value, and how ownership interacts with idiosyncratic volatility to affect the firm specific value component. Section 5 investigates the robustness of our main findings, and section 6 concludes.

\section{Development of Hypotheses and Empirical Methodology}

This section presents our testable hypotheses and empirical methodology. We first elaborate on the background of the development of mutual funds in China, followed by discussions on how the ownership of mutual funds impacts on firm operating performance and value. We then discuss how to isolate the indirect impact that mutual funds have on firm performance from that of informed trading by decomposing the market-to-book ratios, and finally, we investigate the correlation between mutual fund ownership and firm idiosyncratic volatility. 


\subsection{Mutual funds in China}

China's mutual fund market has been growing rapidly since the first open-end mutual fund was established in 2001. According to a recent article published in the China Securities Journal, ${ }^{5}$ China's mutual fund market at the end of 2011 totalled USD339 billion in net assets, while the net fund assets were only USD 10 billion in 2001, an annualized growth rate of $142 \%$. However, the mutual fund market is small in size relative to both the aggregate level of GPD and the total stock market capitalization of China. China's total value of mutual fund investment only accounts for about $4.65 \%$ of its GDP, and the securities investment funds (around $74.45 \%$ of mutual funds investment, Shanghai Stock Exchange Factbook 2012) only account for $7.8 \%$ of total market capitalization compared to $40.03 \%$ and $25.67 \%$ in Brazil, and $76.99 \%$ and $40.28 \%$ in the U.S., respectively. With more than 30 years of development, investors in Chinese stock markets are still dominated by small and medium sized individual investors (51.3\% of market share, China Capital Markets Development Report, 2008).

Despite the rapid development of institutional investors over the past decade, China's stock markets are still characterized by short term investment, a high turnover rate, and a lack of monitoring management by shareholders, even for big institutional investors such as mutual funds, QFIIs, and Social Security funds, etc. It is very difficult for mutual funds in China to have sufficient incentives to monitor the management of their holding stocks given their extremely short investment horizon and high turnover ratio. Table 1 is a distribution table for mutual fund ownership of our sample firms from 2001 to 2010. For individual mutual funds, less than $1 \%$ of the holding falls into the $5 \%$ holding requirement. By assuming that a mutual fund under the same management company could have collective actions on an

\footnotetext{
${ }_{5}^{5}$ Please refer to the relevant article in China Securities Journal on 2012-06-15 for details, or webpage http://www.cs.com.cn/tzjj/jjts/201206/t20120615_3371875.html.
} 
individual firm, we also group ownership by fund management companies. Only slightly more than $1 \%$ of the holdings satisfy the $5 \%$ holding requirement. The percentage of firms that satisfy both criteria is $1.21 \%$.

[Please insert Table 1 here]

A recent study by Chen, Harford, and Li (2007) argue that only independent long term institutions with sufficiently large holdings (more than 5\%) can benefit from their efforts as monitors and be able to share the superior post-merger performance of their monitored firms with other investors. Short term institutional investors may choose to trade on a firm's specific information rather than monitor the firm. Yan and Zhang (2009) also find that only the ownership of institutional investors with high portfolio turnover rate is positively associated with future stock returns and future earnings surprises because they are more likely to be better informed than their low portfolio turnover rate counterparts. In order to distinguish the informational argument from the monitoring argument, we need the institutional investors to satisfy two criteria, holding a large state in stocks (more than 5\%) and holding for a long period (over 12 months). It is clear that mutual funds in China are short term institutional investors because most of them do not meet the two criteria for long term investors.

\subsection{Mutual fund ownership and firm performance}

A recent study by Yuan et al. (2008) finds that mutual fund ownership in China is positively associated with both firm operating performance and firm value. They contribute this positive association to a possible monitoring role played by the mutual funds. In contrast, Firth, Lin, and Zou (2010) indicate that mutual funds even lack the incentive to bargain for their own compensation during the negotiation process of the split share structure reform during the 
period from 2005-2006. It is hard to link the positive association of firm performance and mutual fund ownership with the monitoring role played by the mutual funds. Following Yuan et al. (2008), we expect to find that mutual fund ownership in China is positively associated with operating performance and firm value by using a longer time period, from 2001 to 2010 . Our first hypothesis is listed as follows:

H1: Mutual fund ownership is positively related to firm operating performance and firm value (Market-to-Book equity ratio).

We choose three firm performance measures that have been widely used in the literature: market-to-book equity ratio (MTB), return on assets before depreciations and amortizations (ROA), and net income (NI). Firm operating performance may vary from industry to industry. It is important to have a proper control over the industry effect so we use industry adjusted performance measures (performance measures are adjusted by their China Securities Regulatory Commission or CSRC industry median). After controlling extraneous industry effects such as industry adjusted comparisons which help to analyse firm specific performance irrespective of any industry wide factors that may affect firm performance measures (Cornett et al., 2007), our baseline regression models are as follows:

$$
\begin{aligned}
& \text { InadjMTB }_{i, t}=\beta_{0}+\beta_{1} \text { FundHLD }_{i, t-1}+\beta_{2} \text { StateHLD }_{i, t-1}+\beta_{3} \text { FIIHLD }_{i, t-1}+\beta_{4} \text { SSHLD }_{i, t-1} \\
& +\beta_{5} T_{A N G_{i, t}}+\beta_{6} L E V_{i, t}+\beta_{7} \operatorname{SIZE}_{i, t}+\beta_{8} T_{U R N_{i, t}}+\beta_{9} E X R E T_{i, t}+\beta_{10} \text { FFINDEX }_{i, t}+\alpha_{1 i}+\delta_{1 t}+\varepsilon_{i, t} \\
& \text { InadjROA }_{i, t}=\beta_{0}+\beta_{1} \text { FundHLD }_{i, t-1}+\beta_{2} \text { StateHLD }_{i, t-1}+\beta_{3} \text { FFIHLD }_{i, t-1}+\beta_{4} \text { SSHLD }_{i, t-1} \\
& +\beta_{5} \operatorname{TANG}_{i, t}+\beta_{6} \mathrm{LEV}_{i, t}+\beta_{7} \operatorname{SIZE}_{i, t}+\beta_{8} \operatorname{TURN}_{i, t}+\beta_{9} \operatorname{EXRET}_{i, t}+\beta_{10} \text { FFINDEX }_{i, t}+\alpha_{2 i}+\delta_{2 t}+\mu_{i, t} \\
& \text { Inadj }_{i, t}=\beta_{0}+\beta_{1} \text { FundHLD }_{i, t-1}+\beta_{2} \text { StateHLD }_{i, t-1}+\beta_{3} \text { QFIIHLD } D_{i, t-1}+\beta_{4} \text { SSHLD }_{i, t-1} \\
& +\beta_{5} T_{A N G_{i, t}}+\beta_{6} L_{E V_{i, t}}+\beta_{7} \operatorname{SIZE}_{i, t}+\beta_{8} T_{U R N_{i, t}}+\beta_{9} \text { EXRET }_{i, t}+\beta_{10} \text {HFINDEX }_{i, t}+\alpha_{3 i}+\delta_{3 t}+\kappa_{i, t}
\end{aligned}
$$


where $\alpha$ and $\delta$ are firm fixed effects and time fixed effects, respectively. Market-to-book ratio (MTB) is defined as the market value of equity divided by the book value of equity. This measure of performance reflects a firm's growth opportunities (Fama and French, 1995). We use industry adjusted natural log transformed MTB as our performance measure. Cornett et al., (2007) argue that the measures of operating performance provide two incentives over measures of the market value. First, an operating performance measure is a more focused measure of current performance, and unlike market performance measure, it is not inflated by price changes associated with the expectative corporate takeover events. Second, operating performance is not tied to share prices and it does rely on a specific model of expected returns, although market performance could be more susceptible to engodeneity problems if financial institutions (e.g., mutual funds) chase recent market winners or growth stocks. These problems are much more pronounced in emerging stock markets due to frequent price manipulation and poor corporate governance (Wang, 2004). Return on assets (ROA) is defined as operating income before depreciations and amortizations divided by the book value of total assets. This performance measure is considered to be the most common accounting profitability measure in the literature and is used as a proxy for the profitability of a company's core business (Yuan et al., 2008). In order to reconcile the results of ROA with that of the operating performance measure net income (NI) used in the decomposition of market-to-book ratio (Section 2.3), we also report the estimation results using NI (net income scaled by book value of equity). Mutual fund ownership (FundHLD) is the percentage of shares owned by mutual funds in the sample firms, computed as the number of shares held by mutual funds divided by the total shares outstanding. Our mutual fund ownership only measures the ownership of funds incorporated in China. 
To remain consistent with the existing literature we adopt two sets of control variables: ownership-specific and firm-specific variables. Ownership control variables include state ownership and ownership concentration, to control for the effect of state government ownership and concentrated ownership on firm performance. State ownership is historically viewed as an important ownership variable in China, due to state government, and its representatives are normally the largest shareholders or controlling shareholders in many listed firms. The performance of a typical listed firm is often reported to be associated with a substantial level of state ownership (e.g., Xu and Wang, 1999; Wei et al., 2005). This control variable is defined as the percentage of shares that are directly controlled by the state government, if the state government is the largest shareholder in the sampled firms. The ownership concentration (HFINDEX) is computed as the sum of the squared percentage of shares held by the top five largest shareholders provided in CSMAR databases. Shleifer and Vishny (1986) argue that the large shareholders may help to mitigate the agency problem of a firm and in turn, improve the firm's value. Wang (2005) report a positive relationship between the level of ownership concentration and firm performance in China. The ownership of qualified foreign institutional investors (QFIIHLD) is the percentage of shares owned by qualified foreign institutional investors (QFIIs) in the sample firms, computed as the number of shares held by QFIIs divided by the total outstanding shares. The Social security fund ownership (SSHLD) is the percentage of shares owned by social security funds in the sample firms, computed as the number of shares held by social security funds divided by the total number of outstanding shares.

Firm-specific variables include firm size, leverage, asset tangibility, previous 12 month median market turnover, and previous 12 month excess stock returns earnings per share. Definitions of these control variables are presented as follows. Firm size (SIZE) is 
computed as the natural logarithm of total assets at the end of each fiscal year. It has often been argued that size has a negative impact on firm performance (e.g., Demsetz and Lehn, 1985). Leverage (LEV) is a debt-to-asset ratio, computed as the book value of total debts divided by the book value of total assets at the end of each fiscal year. Both Sun and Tong (2003) and Qi et al. (2000), find that leverage is positively related to the market-to-bookvalue ratio but negatively related to accounting returns in China. Tangibility (TANG) is computed as the tangible assets divided by the book value of total assets at the end of each fiscal year. Firms with lower asset tangibility presumably have a higher proportion of intangible assets (e.g., human capital) to generate cash flows. We use the previous 12 month market-adjusted stock return of the firm (EXRET) to control for the market expectation realized in past stock returns about a firm's prospects. The excess returns are calculated by deducting the aggregated market return from the firm's realized returns. Following Gompers and Metrick (2001) and Yan and Zhang (2009) we also use past turn over (TURNOVER, median monthly turnover over the past 12 months) as the additional variables to control for trading volatility. The baseline regression model used in this study is the firm fixed effects model. To mitigate the effects of time we include year dummies in all the regressions to control for variations in the macroeconomic environment across time.

\subsection{Firm operating performance and decomposition of Market-to-Book ratio}

The baseline regressions in Section 2.2 can only investigate whether mutual fund ownership is associated with firm operating performance or with firm value independently. However, it cannot identify the source of a high market-to-book ratio or whether the high market-to-book ratio is driven by an improved operating performance because of an indirect influence by mutual funds on firms' operations through selling their holdings ("voting by feet"), or is 
driven by informed trading on firm specific information gathered by the mutual funds. Since there are multiple factors driving the increase in MTB, ROA is only representing factors related to current operating performance. It is therefore necessary for us to further explore the value sources of MTB by decomposition and then to understand whether informed trading also contributes to the high MTB ratio.

A lot of previous studies use decomposed components of the MTB ratio to explore the value driving factors behind a high MTB ratio (e.g., Daniel and Titman 2006; Fang, Noe and Tice 2009; Hertzel and Li 2010; Ma, Q., Whidbee, D. A., Zhang, W., 2011; Resutek 2010; Rhodes-Kropf et al. 2005, among others). For example, in order to further investigate the source of high firm market-to-book ratio, Fang, Noe and Tice (2009) decompose the marketto-book ratio into price-to-operating earnings, financial leverage, and operating profitability, and find that the relationship between liquidity and firm performance is mainly due to efficient pricing. Motivated by a methodology developed in Rhodes-Kropf, Robinson, and Viswanathan (RKRV) (2005) and also use in Hertzel and Li (2010), we decompose the MTB ratios into a component related to operating performance, a component of misevaluation, and a growth option component. This decomposition enables us to further investigate the real driving force behind the MTB ratios without the influence of firm operating performance. More specifically, The RKRV (2005) methodology uses an accounting multiples approach to break the MTB ratios into three components: firm-specific error (FSE), time-series sector error (TSSE), and long-run value-to-book (LRVTB). The FSE component measures firm specific deviations from valuations implied by current sector (industry) accounting multiples and is intended to capture the extent to which a firm is mis-valued relative to its contemporaneous industry peers (the focus of this study). The TSSE component measures valuation deviations when contemporaneous sector accounting multiples differ from long 
term sector multiples, hence this component is used to measure whether the sector or the entire market, is overvalued. The LRVTB component measures the value implied by long term sector accounting multiples relative to book value; it is used as a proxy for growth opportunities. Specifically, the three components are estimated using the following model specification:

$L N M V E_{i t}=\alpha_{0 j t}+\alpha_{1 j t} L N B V E_{i t}+\alpha_{2 j t} L N(N I)_{i t}^{+}+\alpha_{3 j t} I_{(<0)} L N(N I)_{i t}^{+}+\alpha_{4 j t} M K T L E V_{i t}+\sigma_{i t}$

which includes the natural logarithm of market value of equity (LNMVE), the natural logarithm of book value of equity (LNBVE), the natural logarithm of net income LN(NI), and market leverage (MKTLEV) ratio (book value of debt over market value of equity). Since NI can sometimes be negative, it is expressed as an absolute value (NI)+ along with a dummy variable, $I(<0)$, to indicate when NI is negative. To calculate the contemporaneous accounting multiples $\alpha_{j t}$ each year, we group all sample firms according to the 12 CSRC industry classifications: run annual, cross sectional regressions (of the decomposition equation) for each industry, and then generate estimated industry accounting multiples for each year $t$. The estimated value of $\mathrm{V}_{-}$hat is the fitted value from regression equation. To calculate the long term sector multiples $\alpha_{j}$, we average the $\alpha_{j t}$ from the annual regressions over the sample years prior to the ownership event. The estimate of V_bar is then the "fitted" value of the equation using the average $\alpha_{j t}$. From the regression model $V_{-}$hat, the predicted value from the regression really captures the value contribution from assets in place, and market leverage and current earnings that are available to equity holders. We then use the following calculations to make FSE free from the influence of current earnings.

LNMTB $=$ LNMVE - LNBVE, is our market-to-book ratio used as firm market performance. $F S E=L N M V E-V$ hat, is firm specific misevaluation relative to their industry peers. 
$T S S E=V \_h a t-V \_$bar, is valuation deviations from industry long-run.

$L R V T B=V \_$bar $-L N B V E$, is growth opportunities, or long-run industry mean relative to

book value of equity.

[Please insert Table 2 here]

Table 2 reports the estimated coefficients and all the above defined variables calculated from the equations. This estimation is consistent with that reported in Hertzel and Li (2010) using the U.S. sample. The high $R^{2}$ indicates that the specification of the decomposition model indeed has sufficiently high explanatory power for the market value of equity. Using the decomposed components of MTB, we test whether mutual fund ownership is positively associated with these three components, in particular firm specific mis-evaluation of FSE. According to the informational hypothesis, short term mutual funds are likely to trade on firm specific information gathered, rather than do monitoring. Since our sampled mutual funds are unlikely to hold a large state in stocks (more than 5\%), and only hold them for a short period (less than 12 months), our second testable hypothesis is:

H2: Mutual fund ownership is positively related to firm specific misevaluation component of value (FSE).

\subsection{Mutual fund ownership, idiosyncratic volatility, and firm specific valuation}

It is well established in the literature that institutional ownership or mutual fund ownership is closely related to information flow, and idiosyncratic volatility in stock returns is a good proxy for information flow (Roll 1988; Durnev et al. 2003). Piotroski and Roulstone (2004) investigate the association between idiosyncratic volatility and institutional trading, and find 
that institutional trading activities accelerate the incorporation of the firm specific information of earnings into stock prices. Recent studies by Sias, Starks, and Titman (2006) and Ferreira and Lux (2007) all support an information flow link for the association between changes in stock prices and institutional trading. Sias, Starks, and Titman (2006) argue that institutional trading has both temporary and permanent price impacts on stocks and these impacts in stock prices are associated with information flow. Ferreira and Lux (2007) find that firms' openness to the market for corporate control encourages informed trading by institutions and is positively associated with the idiosyncratic volatility related to information. To further explore the information aspects of the effect of valuation on institutional ownership, we first explore the time serial correlation of idiosyncratic volatility and institutional ownership from 2001 to 2010 in China. Table 3 indicates that the average idiosyncratic volatility has a positive association with the average institutional holdings over our sample periods, which is consistent with the empirical evidence documented in the literature.

[Please insert Table 3 here]

Since the firm specific misevaluation component of value (FSE) is related to the flow of firm specific information we should expect there is a positive association between FSE and idiosyncratic volatility, but to consistent with the informational hypothesis, the positive association between FSE and mutual fund ownership should be more pronounced for firms with high idiosyncratic volatility.

H3: Idiosyncratic volatility is positively related to firm specific misevaluation component of value (FSE), and the interaction between mutual fund ownership and idiosyncratic volatility is positively related to FSE. 


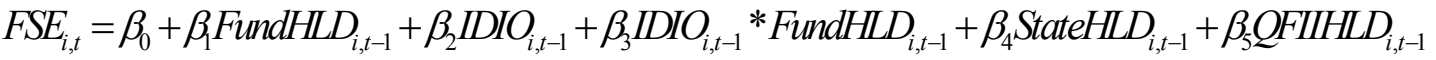

$$
\begin{aligned}
& +\beta_{6} \mathrm{SSHLD}_{i, t-1}+\beta_{7} \operatorname{TANG}_{i, t}+\beta_{8} \mathrm{LEV}_{i, t}+\beta_{9} \mathrm{SIZE}_{i, t}+\beta_{10} T U R N_{i, t}+\beta_{11} \mathrm{EXRET}_{i, t}+\beta_{12} \operatorname{HFINDEX}_{i, t}+\alpha_{4 i}+\delta_{4 t}+\eta_{i, t}
\end{aligned}
$$

where FSE is the firm specific misevaluation component of value computed in Section 2.3 and idiosyncratic volatility (IDIO) is defined as the standard deviation of estimated stock return residuals in the previous fiscal year. Specifically, we estimate the CAPM model for each firm-year daily stock returns and compute the standard deviation of estimated residuals from the market asset pricing models. ${ }^{6}$ Idiosyncratic volatility captures a firm's specific variation beyond what has been reflected in market asset pricing model. All the other variables are defined as in Section 2.2. A significant and positive coefficient $\beta_{2}$ and $\beta_{3}$ will support our informational hypothesis that both information flow and mutual fund ownership are associated with the firm specific valuation component.

\section{Data Sample}

Our initial sample contains all the firms from the mutual fund shareholding databases of the China Stock Market and Accounting Research (CSMAR), which consists of all firms that are listed on the Shanghai Stock Exchange and Shenzhen Stock Exchange and are held by at least one mutual fund. The sample period is from 2001 to $2010^{7}$. We match the ownership data with stock returns and accounting information for the Chinese A shares available at CSMAR with the following criteria:

1. Firms with missing mutual fund ownership information are excluded.

\footnotetext{
${ }^{6}$ Alternatively, we use idiosyncratic volatility estimated from the residuals using the Fama and French (1993) asset-pricing model for daily stock returns in the past fiscal-year. Our empirical results are similar.

${ }^{7}$ The first open-end mutual fund launched in 2001 in China. From 2001, the CSRC gradually simplified the fund approval process and reduced control to mutual fund industry. Our sample starts with the availability of the information of open-end funds.
} 
2. Firms with missing accounting and stock market information are excluded.

3. Firms with negative book value of equity are excluded.

4. Firm-year observations in their first IPO year are excluded.

5. Firms in finance and insurance industry are excluded (with CSRC Industry Classification code "I")

The final sample consists of 12,852 firm-year observations. The measurement of 13 industry classifications is issued by the China Securities Regulatory Commission (the CSRC).

[Please insert Table 4 here]

Table 4 reports the summary statistics of all the key variables that will be used in the next section in our empirical tests. From Panel A, on average, $4 \%$ of a firm's A shares are held by mutual funds (FundHLD), and only around $0.2 \%$ and $0.7 \%$ are held by QFIIs and Social Security funds, respectively. However, the state government controls around $22.1 \%$ of the A shares in our sample period. The natural log transformation of market-to-book equity ratios (LNMTB) and ROA are comparable to those reported in other empirical studies. An average annual stock turnover of $41.8 \%$ (with a median of $30.2 \%$ ) is significantly large, which is consistent with the fact that all investors in China tend to hold stocks for a short time and trade frequently. This observation is also consistent with our argument that most of investors in China, even mutual funds, are focusing on short term trading. Panel B reports the annual distribution of the sample. The firm-year observations gradually increase from 2001 to 2010 and the time variation is reasonable since we exclude all observations in their first IPO year. Panel $\mathrm{C}$ presents the CSRC industry distributions of the sample. Just like other Chinese studies, manufacturing firms account for $56 \%$ of our sample.

Table 5 reports the pair-wise correlations among the key variables. It is worth noting that FundHLD is positively correlated with LNMTB and ROA, indicating that high fund 
ownership is associated with high firm value and operating performance. The correlations between FundHLD, SIZE and LEV are also consistent with the empirical literature that mutual funds tend to avoid high leverage firms and hold large firms.

[Please insert Table 5 here]

\section{Empirical Results}

In this section we test our three hypotheses developed in Section 2. To mitigate the endogeneity present when estimating the association between firm value and mutual fund ownership, we use lagged one year ownership variables as key explanatory variables, although we cannot rule out the possibility of omitted variable bias, or unobserved firm heterogeneity. In this situation, lagged mutual fund ownership and firm value are spuriously correlated and they are both driven by some unobservable firm characteristic(s). We use the firm fixed effect model to mitigate the endogeneity caused by unobservable firm heterogeneity, and also include year dummy variables in our regressions to control for possible time effects. All the variables have been winsorized at the 0.5 th and 99.5 th percentiles because this approach reduces the impact of extreme observations by assigning cut off value to values beyond the cut-off point. ${ }^{8}$

\subsection{Mutual fund ownership and firm performance}

Table 6 presents estimates from the baseline specification (equations (1), (2) and (3)) using the firm fixed effects model. The coefficient estimates on lagged mutual fund holdings are

\footnotetext{
${ }^{8}$ Our results are qualitatively very similar when we truncate the distribution instead of winsorizing it.
} 
statistically significant and positive at the $1 \%$ level for firm value (INADJ_LNMTB) and operating performance (INADJ_ROA), and at 5\% level for net income (INADJ_NI) that we used in Section 2.2 the decomposition of market-to-book ratios. This is consistent with Cornett et al., (2007) and Yuan et al. (2008) that larger mutual fund ownership is associated with higher firm value and better firm operating performance. It also supports Chen, Harford and Li (2007) and Yan and Zhang (2009), that the presence of mutual funds in a firm's shareholdings is associated with positive economic gains for the firm. In addition, QFIIHLD is positively correlated with firm performance. This confirms the argument by Ferreira and Matos (2008) and Aggarwal, et al. (2011) that foreign institutional investors can enhance firm performance in countries with weak shareholder protection. The controlling status of state government and Social Security funds is largely not associated with firm performance (statistically insignificant). The ownership concentration (HFINDEX) is positively correlated with firm performance, which is consistent with the findings by Wang (2005) and the prediction proposed by Shleifer and Vishny (1986).

[Please insert Table 6 here]

\subsection{Mutual fund ownership and the decomposition of MTB}

The empirical results of the baseline regressions in Section 4.1 support our first hypothesis that mutual fund ownership is positively correlated with both firm value and firm operating performance. However, these estimations cannot identify whether the increase in firm value associated with fund ownership is driven purely by an increase in operating performance through an increased monitoring role played by mutual funds (the monitoring hypothesis), or by facilitating private information incorporated into stock prices through their informed trading (the informational hypothesis). The market-to-book ratio has been widely used in 
asset pricing literature as an indicator of a firm's long term prospects. There are multiple factors driving an increase in the firm value proxy (MTB), and the operating performance measure (both ROA and Net Income) only represents the current performance of a firm.

In order to separate the contribution made by current operating performance from those made by other factors, we use a decomposition methodology developed in Rhodes-Kropf, Robinson, and Viswanathan (RKRV) (2005) to further investigate whether mutual fund ownership is associated with all three decomposed components of MTB, as detailed in Section 2.2. Since the firm specific error component of FSE captures firm level mispricing relative to its contemporaneous industry peers, our focus in this section is to see whether mutual fund ownership affects firm value through this mispricing component that is likely to be correlated with firm specific information. Table 7 presents the estimated results for the association between three decomposed components of firm value and mutual fund ownership. We use the three components estimated in Section 2.2 as dependent variables to rerun our baseline firm value model. As expected, all three valuation components are positively associated with mutual fund ownership, while the firm specific component (FSE) regression has the largest coefficient of 0.650 , which is more than twice the coefficient of 0.275 for the long term growth component (LRVTB) regression, and five times the coefficient of 0.116 for the industry sector value component (TSSE) regression. This evidence supports our second hypothesis that mutual fund ownership is more likely to enhance firm specific valuation because funds have expertise in gathering and collecting on firm specific information (Piotroski and Roulstone 2004).

The significant association between QFIIs ownership and LRVTB and TSSE show that foreign intuitional investors in China are engaging in long term and industry specific investment, which is consistent with their prudent investment policy documented in the U.S. 
markets. The state controlling ownership is negatively related to FSE and positively related to TSSE. Overall, our findings support a positive association between firm specific value and mutual fund ownership.

[Please insert Table 7 here]

\subsection{Mutual fund ownership, idiosyncratic volatility and firm specific valuation}

In this section we formally test our informational hypothesis (Hypothesis 3) and investigate whether idiosyncratic volatility is associated with firm specific value component FSE, and whether mutual fund ownership and idiosyncratic volatility interacts to affect FSE. Idiosyncratic volatility is a widely accepted measure for the informativeness of stock prices, or for the flow of firm specific information. As with Gul, Kim and Qiu (2010), we apply the Capital Asset Pricing Model (CAPM $)^{9}$ and regress all past year daily stock returns of our sampled firm on aggregated Shanghai and Shenzhen Stock Exchange value-weighted market returns, and extract the residuals from the model estimations. We then compute the annual standard deviation of the residuals for each firm in each year.

[Please insert Table 8 here]

To test the information hypothesis, we first add idiosyncratic volatility as an additional variable into our FSE regressions to see whether firm specific information flow is correlated with the firm specific value component. In Column (2) of Table 8, the correlation between

\footnotetext{
${ }^{9}$ Alternatively, we use the Fama and French (1993) three-factor model or CAPM augmented with industry returns to estimate the residuals. Since the pairwise correlation between these idiosyncratic volatility measures estimated from these three different approaches is over $95 \%$, for brevity, we do not report other idiosyncratic volatility measures here.
} 
FSE and idiosyncratic volatility is 0.771 . The coefficient on FUNDHLD changes slightly from 0.650 in Column (3) of Table 7 to 0.628. Both the coefficients on FUNDHLD and idiosyncratic volatility are statistically significant at the $1 \%$ level, which indicates that the flow of firm specific information and mutual fund ownership act independently on firm value. In other words, mutual fund trading is not the only channel through which firm specific information is incorporated into firm value. When we interact idiosyncratic volatility with mutual fund ownership in Column (3), the coefficient on the interactive term is positive and significant at the $1 \%$ level. Both coefficients on FUNDHLD and idiosyncratic volatility decrease slightly but remain highly significant. This evidence supports our argument regarding information flow for mutual fund ownership that informed trading by mutual funds facilitates the incorporation of firm specific information into firm value. In other words, these findings confirm that a link exists between information flowing from mutual fund ownership to firm specific valuation. For a firm with an average idiosyncratic volatility of 0.118 (Table 3), a 1 percentage point increase in mutual fund holdings is associated with $0.118 * 0.01 * 1.749=0.21 \%$ increase in firm specific value relative to their industry median, or an increase of $8.4 \%$ of average industry-adjusted FSE (with an average value of 0.025 in our sample).

\section{Robustness checks}

\subsection{Changes in the number of mutual funds}


The firm fixed effects model used in Section 4 alleviates the concern for endegeneity caused by unobserved firm heterogeneity, but the model is silent on endogeneity caused by reverse causality. In other words, it is possible for a firm with high value to attract more mutual funds to buy its shares $^{10}$ rather than the high ownership by mutual funds improves a firm's valuation. In addition Sias, Starks, and Titman (2006) argue that stock prices should be correlated with net fund order flow since the aggregate demand for stocks by mutual funds will push up stock prices when non-fund investors have an upward sloping supply curve. They propose an alternative measure for informed trading by mutual funds by changing the number of mutual funds holding a stock. Similar to the breadth of ownership used by Chen, Hong and Stein (2002), changes in the number of mutual funds reflect changes in the number of informed traders in stock markets. When short sales constraints are binding, investors with negative information about a stock will sit on the sidelines in which reduces the number of mutual fund holders.

In order to address these two concerns, we use quarterly mutual fund shareholding databases of CSMAR to construct two proxies for informed trading, average annual changes in fund ownership (CHGFUNDHLD) and average annual changes in the number of mutual funds holding a stock (CHGFUNDNUM). The sample size is reduced to 6,269 firm year observations since the holding data of CSMAR is available only after 2003. We also use lagged CHGFUNDHLD and lagged CHGFUNDNUM to further mitigate the reserve causality problem. We then re-estimate Equation (5) and use these two new proxies to replace the level variable (FUNDHLD). Our approach here is essentially change-in-change since the

\footnotetext{
${ }^{10}$ Our model specification of using lagged ownership variables (Equation (5)) cannot rule out the possibility that lagged high firm value caused the current high fund ownership since firm value is, in general, time-serially correlated.
} 
dependent variable FSE, is a component of the natural log transformation of market-to-book ratios. As a comparison, we also report the results of pooled-OLS regressions in the table.

\section{[Please insert Table 9 here]}

Table 9 presents the results of the association between the firm specific component (FSE) and the two new proxies. Notably, the coefficients on lagged CHGFUNDHLD and lagged CHGFUNDNUM are positive and significant across all four columns. The estimated coefficients for CHGFUNDNUM range from 0.345 to 0.698 . Table 10 reproduces the results reported in Table 8 using the two new proxies. The coefficients of interest, the interactions between CHGFUNDHLD and CHGFUNDNUM with IDIO are positive and statistically significant at the $1 \%$ level. Taken together, this change-in-change approach alleviates concerns about potential reverse causality and further confirms the information hypothesis that informed trading by mutual funds improves the incorporation of firm specific information into firm specific value.

[Please insert Table 10 here]

\subsection{Share-split structure reform}

To address concerns about reverse causality we also use a quasi-natural experimental approach to see how informational environment and mutual fund holdings respond to the Split Share Structure Reform that happened in China from 2005 to 2007. The unique sharesplit ownership structure in China means that only a small fraction of the shares of publicly listed Chinese companies are freely tradable in the secondary market. According to CSRC, this fraction was only $28.4 \%$ at the end of 2005 . The distorted holding structure reduced corporate governance and transparency (Gul et al., 2010), which increased the uncertainty of a firm's value. Following the initiation of the Split Share Structure Reform in 2005, many 
companies started the process of making their non-tradable shares fully tradable in the secondary markets. This reform is likely to improve the informational environment in the secondary stock markets and to provide great incentives for mutual funds to collect and trade on their private information.

To identify the effect of mutual fund ownership on firm specific value, we estimate the following difference-in-difference model specification:

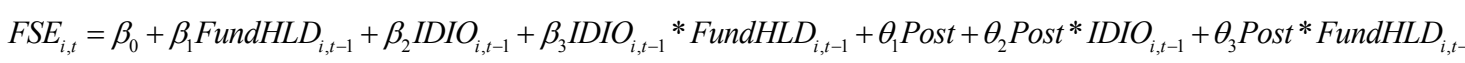

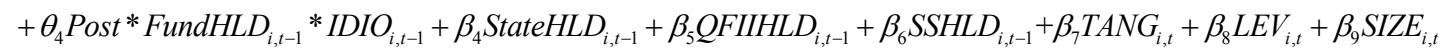

$$
\begin{aligned}
& +\beta_{10} T U R N_{i, t}+\beta_{11} E X R E T_{i, t}+\beta_{12} \operatorname{HFINDEX}_{i, t}+\alpha_{5 i}+\delta_{5 t}+\varepsilon_{i, t}
\end{aligned}
$$

where Post is a dummy variable that equals one if a firm has completed its split share structure reform and 0 otherwise. The positive coefficients on the interactions between Post with FUNDHLD and between Post with IDIO indicate improvement in the economic impact of fund holding and informational environment after the reform, respectively. The positive coefficient of the interaction term Post*FUNDHLD*IDIO measures whether mutual funds have more incentives to trade on their informational advantage after the share split structure reform than they do before the reform. Table 11 displays the estimates for the difference-indifference approach in a firm fixed effects model. As expected, both the coefficients on the interactions Post*FUNDHLD and Post*IDIO are positive and significant (in Column (3)). Surprisingly, the coefficient on Post*FUNDHLD*IDIO is negative and significant $(-3.953$ with t-statistics of -4.63). However, the interpretation of the coefficient on this triple interaction term also depends the other interactions Post*FUNDHLD and Post*IDIO.

\section{[Please insert Table 11 here]}

In order to illustrate the complex effect of interactions reported in Table (11), we provide an example with four different representatives of the sampled firms, namely HFHI (high mutual fund ownership and high idiosyncratic volatility), HFLI (high mutual fund 
ownership and low idiosyncratic volatility), LFHI (low mutual fund ownership and high idiosyncratic volatility) and LFLI (low mutual fund ownership and low idiosyncratic volatility). Specifically, low mutual fund ownership firms are firms at the $25^{\text {th }}$ percentile of FUNDHLD (with a value of $0 \%$ ) and high mutual fund ownership firms are firms at the 75th percentile of FUNDHLD (with a value of 5.9\%) in the sample. Low idiosyncratic volatility firms are firms at the 25th percentile of IDIO (with a value of 0.0567 ) and high idiosyncratic volatility firms are firms at the 75th percentile of IDIO (with a value of 0.1648 ) in the sample. Table 12 displays regression coefficients calculated for these four representatives before and after the reform. Before the reform, increasing fund ownership from Low to High for the Low-idiosyncratic-volatility firms, the firm specific value increases by 0.0263 , while increasing fund ownership from Low to High for the High-idiosyncratic-volatility firms, the firm specific value increases by 0.0416 . However, after the reform, the firm specific value increases by 0.0537 for the Low-idiosyncratic-volatility firms, an increase of 0.027 due to the reform, indicating both improvements in informational environment and in incentives for mutual funds to trade on their informational advantage. However, for the High-idiosyncraticvolatility firms, the increase is only 0.0022 , which is almost negligible. Furthermore, after the reform the incentives for mutual fund trading are reduced for the High-idiosyncratic-volatility firms. This partly explains the negative coefficient on Post*FUNDHLD*IDIO in Table 11. We reason that after the reform, non-tradable shares for the High-idiosyncratic-volatility firms now become tradable (untabulated results show that these firms are less likely to be controlled by state government). The controlling shareholders of these firms become informed trader, having informational advantage to mutual funds. That is probably the reason why the mutual funds' information role has been discouraged for this particular group of firms. 
[Please insert Table 12 here]

\section{Conclusion}

Mutual fund ownership or mutual fund trading is an important channel through which information is incorporated into stock prices. Extant literature indicates that improvement in the informativeness of stock prices by informed trading of mutual funds is mainly reflected in its association with firm specific volatility, or idiosyncratic volatility (Piotroski and Roulstone, 2004; Ferreira and Lux 2007). The existence of informed mutual fund trading in China is likely to mitigate informational impediments and to improve the informativeness of stock prices by facilitating the incorporation of private information into firm value. Our informational hypothesis emphasizes the importance of mutual fund trading in Chinese stock market, which has long been characterised as a lack of market informativeness in stock prices due to poor investor protection (Morck, Yeung and Yu 2000), or less transparent accounting information (Gul, Kim and Qiu 2010).

In this paper we test an informational link from mutual fund ownership to firm specific value using mutual fund ownership data from 2001 to 2010 . We first verify the positive association between mutual fund ownership and firm value and then use a decomposition methodology developed in Rhodes-Kropf, Robinson, and Viswanathan (RKRV) (2005) to test whether the firm specific value (FSE) is associated with mutual fund holdings. Finally, we test the interaction between mutual fund ownership and firm specific information (idiosyncratic volatility) and examine the effect of the interaction on firm specific values. The overall empirical evidence supports our informational hypothesis that mutual fund ownership is positively associated with a firm specific valuation component through an increase in the in formativeness of stock prices (idiosyncratic volatility). Our findings are robust to alternative 
measures for mutual fund holdings, alternative change-in-change approach, and a quasinatural experiment of the Split Share Structure Reform in China.

A few recent studies have found that foreign ownership, institutional ownership (especially mutual fund ownership), and high quality auditing, help to mitigate informational impediments and to improve the informativeness of stock prices by encouraging informed trading in China. Our paper complements the literature by providing an information-tovaluation channel through which mutual fund ownership can be associated with firm specific value.

\section{References}

Aggarwal, Reena, Isil Erel, Miguel Ferreira, and Pedro Matos, 2011, Does Governance Travel Around the World? Evidence from Institutional Investors, Journal of Financial Economics 100, 154-181.

Chen, J., Hong, H., Stein, J., 2002, Breadth of ownership and stock returns. Journal of Financial Economics 66, 171-205.

Chen, X., Harford, J., and Li, K., 2007, Monitoring: Which institutions matter? Journal of Financial Economics, 86, 279-305.

Daniel, K. D., and S. Titman, 2006, Market reactions to tangible and intangible information. Journal of Finance 61, 1605-43

Demsetz, H. \& Lehn, K., 1985, The structure of corporate ownership: Causes and consequences. Journal of Political Economy 93, 1155-77

Durnev, Artyom, Randall Morck, Bernard Yeung, and Paul Zarowin, 2003, Does greater firm specific return variation mean more or less informed stock pricing? Journal of Accounting Research 25, 797-836.

Fama, E.F., French, K.R., 1993, Common risk factors in the returns to stocks and bonds. Journal of Financial Economics 33, 3-56.

Fama, E.F., French, K.R., 1995, Size and Book-to-Market Factors in Earnings and Returns, Journal of Finance 50, 131-155. 
Fang, Vivian, Thomas Noe, and Sheri Tice, 2009, Stock market liquidity and firm value, Journal of Financial Economics 94, 150-169.

Ferreira, Miguel and Paul Laux, 2007, Corporate Governance, Idiosyncratic Risk, and Information Flow, Journal of Finance 62, 951 - 989.

Ferreira, Miguel and Pedro Matos, 2008, The Colors of Institutions' Money: The Role of Institutional Investors Around the World, Journal of Financial Economics 88, 499 - 533.

Firth, M., Lin, C., and Zou, H. (2010). Friend or Foe? The Role of State and Mutual Fund Ownership in the Split Share Structure Reform in China. Journal of Financial and Quantitative Analysis 45, 685-706.

Gompers, Paul A., and Andrew Metrick, 2001, Institutional investors and equity prices, Quarterly Journal of Economics 116, 229-259.

Gul, F.A., Kim, J.B., and Qiu, 2010, Ownership Concentration, Foreign Shareholding, Audit Quality, and Stock Price Synchronicity: Evidence from China, Journal of Financial Economics 95, 425-442.

Hartzell, Jay C., and Laura T. Starks, 2003, Institutional investors and executive compensation, Journal of Finance 58, 2351-2374.

Hertzel, M. G., Li, Z., 2010. Behavioral and rational explanations of stock price performance around SEOs: evidence from a decomposition of market-to-book ratios. Journal of Financial and Quantitative Analysis 45, pp 935-958.

Huang, J., C. Sialm, and H. Zhang, 2011, Risk Shifting and Mutual Fund Performance, Review of Financial Studies 24, 2575-2616.

Ma, Q., Whidbee, D. A., Zhang, W., 2011, Value, valuation, and the long-run performance of merged firms. Journal of Corporate Finance 17, 1-17.

Morck, Randall, Bernard Yeung, and Wayne Yu, 2000, The information content of stock markets: Why do emerging markets have synchronous price movements? Journal of Financial Economics 25, 215-260.

Parrino, R., Sias, R.W., and Starks, L.T., (2003) Voting with their feet: Institutional ownership changes around forced CEO turnover. Journal of Financial Economics 68, 3-46.

Piotroski, Joseph D., and Darren T. Roulstone, 2004, The influence of analysts, institutional investors, and insiders on the incorporation of market, industry, and firm-specific information into stock prices, Accounting Review 79, 1119-1151. 
Qi, D., Wu, W., and Zhang, H., 2000, Shareholding structure and corporate performance of partially privatized Firms: Evidence from listed Chinese companies, Pacific-Basin Finance Journal 8, 587-610

Resutek, R. 2010. Intangible returns, accruals, and return reversal: A multiperiod examination of the accrual anomaly. The Accounting Review 85: 1347-1374.

Rhodes-Kropf, M., D. T. Robinson, and S. Viswanathan. 2005. Valuation waves and merger activity: the empirical evidence. Journal of Financial Economics 77: 561-603.

Roll, R., 1988, R-Squared, Journal of Finance 43, 541-566.

Shleifer, A and Vishny, R. W., 1986, Large Shareholders and Corporate Control. Journal of Political Economy 94, 461-88.

Sias, Richard W., Laura T. Starks, Sheridan Titman 2006, Changes in institutional ownership and stock returns: Assessment and methodology, Journal of Business 79, 2869-2910.

Sun, Q. and Tong, W.H.S., 2003, China Share Issue Privatisation: The Extent of its Success. Journal of Financial Economics 70, 183-222.

Tang, K., W. Wang, Rong Xu 2012, Size and performance of Chinese mutual funds: The role of economy of scale and liquidity, Pacific-Basin Finance Journal 20, 228-246.

Wang, C., 2004, Relative strength strategies in China's stock market: 1994-2000, Pacific Basin Finance Journal 12, 159-177.

Wang, C., 2005, Ownership and operating performance of Chinese IPOs, Journal of Banking and Finance 29, 1835-1856.

Wei, Z., Xie, F. and Zhang, S., 2005, Ownership Structure and Firm Value in China's Privatized Firms: 1991-2001. Journal of Financial and Quantitative Analysis, 40 (1), 87-108.

Xu, X., and Wang, Y., 1999, Ownership structure and corporate governance in Chinese stock companies. China Economic Review 10, 75-98.

Yan, Xueming, and Zhe Zhang, 2009, Institutional investors and equity returns: Are shortterm institutions better informed? Review of Financial Studies 22, 893-924.

Yuan, R., Xiao, J. Z., and Zou, H., (2008) Mutual funds' ownership and firm performance: Evidence from China. Journal of banking and finance 32, pp.1552-1565 


\section{Table 1 Distribution of Mutual Fund Ownership 2001 to 2010}

This table reports the distribution of the average fractions of mutual fund ownership for the sampled firms for the period 2001-2010. Individual fund ownership is the average of total percentage ownership by individual mutual funds. Fund management company ownership is the average of total percentage ownership grouped by fund management companies of individual mutual funds. Percentage of firms held by long-term mutual fund is percentage of the sample firms held by longterm fund holders. The long-term holders satisfy two criteria, holding a large state in the stocks (more than 5\%) and holding a long period (over 12 months).

\begin{tabular}{lccccccc}
\hline & mean & $\mathrm{p} 5$ & $\mathrm{p} 25$ & $\mathrm{p} 50$ & $\mathrm{p} 75$ & $\mathrm{p} 95$ & $\mathrm{p} 99$ \\
& 0.299 & 0.002 & 0.022 & 0.087 & 0.319 & 1.335 & 2.831 \\
& & & & & & & \\
Individual fund ownership & 0.647 & 0.004 & 0.046 & 0.194 & 0.704 & 2.918 & 5.806 \\
$\begin{array}{l}\text { Fund management company } \\
\text { ownership }\end{array}$ & & & & & & & \\
$\begin{array}{l}\text { Percentage of firms held by long- } \\
\text { term mutual fund holders }\end{array}$ & $1.21 \%$ & & & & & & \\
\hline
\end{tabular}




\section{Table 2 Time-Series Average of Decomposition Regression Coefficients}

This table reports the time-serial average of decomposition regression coefficients of the following model across 12 China Securities Regulatory Commission (CSRC) industries from 2001 to 2010.

$$
L N M V E_{i t}=\alpha_{0 j t}+\alpha_{1 j t} L N B V E_{i t}+\alpha_{2 j t} L N(N I)_{i t}^{+}+\alpha_{3 j t} I_{(<0)} L N(N I)_{i t}^{+}+\alpha_{4 j t} M K T L E V_{i t}+\sigma_{i t}
$$

The model includes the natural logarithm of market value of equity (LNMVE), the natural logarithm of book value of equity (LNBVE), the natural logarithm of net income LN(NI), and market leverage (MKTLEV) ratio. NI is expressed as an absolute value (NI)+ along with a dummy variable, $\mathrm{I}(<0)$, to indicate when NI is negative. All the estimated coefficients are reported in Panel A. In Panel B, LNMTB is defined as LNMVE - LNBVE, FSE is defined as LNMVE - V_hat, representing firm specific misevaluation relative to their industry peers, TSSE is equal to $\mathrm{V}$ hat $-\mathrm{V} \_$bar, representing valuation deviations from industry long-run, and LRVTBis equal to V_bar - LNBVE, representing growth opportunities, long-run industry mean relative to book value of equity The reported variables are industry-adjusted by subtracting their CSRC industry median. A is Agriculture, forestry and fishery industry, B is Mining industry, C is Manufacturing industry, D is Energy industry, E is Construction industry, $\mathrm{F}$ is Transport and storage industry, $\mathrm{G}$ is Information Technology industry, $\mathrm{H}$ is Wholesale and retail trade industry, $\mathrm{J}$ is Real estate industry, $\mathrm{K}$ is Social service industry, L is Communication and Cultural Industry and $\mathrm{M}$ is Comprehensive industry.

\begin{tabular}{lcccccccccccc}
\hline \hline CSRC & $\mathrm{A}$ & $\mathrm{B}$ & $\mathrm{C}$ & $\mathrm{D}$ & $\mathrm{E}$ & $\mathrm{F}$ & $\mathrm{G}$ & $\mathrm{H}$ & $\mathrm{J}$ & $\mathrm{K}$ & $\mathrm{L}$ & $\mathrm{M}$ \\
\hline$\alpha_{0}$ & 6.089 & 6.111 & 8.495 & 5.884 & 5.757 & 4.944 & 7.276 & 9.278 & 9.217 & 9.598 & 8.279 & 8.065 \\
$\alpha_{1}$ & 0.638 & 0.667 & 0.486 & 0.642 & 0.568 & 0.662 & 0.522 & 0.471 & 0.496 & 0.425 & 0.542 & 0.558 \\
$\alpha_{2}$ & 0.142 & 0.131 & 0.187 & 0.154 & 0.251 & 0.168 & 0.217 & 0.155 & 0.139 & 0.196 & 0.151 & 0.139 \\
$\alpha_{3}$ & -0.008 & 0.020 & -0.007 & -0.002 & -0.025 & 0.007 & -0.006 & 0.001 & -0.002 & -0.004 & 0.000 & -0.012 \\
$\alpha_{4}$ & -1.133 & -2.816 & -1.359 & -1.409 & -2.146 & -0.320 & -1.588 & -1.072 & -1.643 & -2.151 & -1.713 & -1.685 \\
$R^{2}$ & 0.794 & 0.904 & 0.740 & 0.847 & 0.866 & 0.887 & 0.840 & 0.709 & 0.709 & 0.601 & 0.883 & 0.742 \\
& & & & & & & & & & & & \\
INADJ_LNMTB & 0.054 & 0.036 & 0.052 & -0.023 & -0.094 & 0.019 & 0.026 & 0.054 & 0.097 & -0.023 & -0.024 & 0.078 \\
INADJ_FSE & -0.013 & -0.002 & 0.044 & -0.017 & 0.002 & 0.026 & 0.011 & 0.005 & 0.010 & -0.064 & 0.015 & 0.022 \\
INADJ_TSSE & 0.002 & 0.014 & 0.005 & 0.007 & 0.002 & -0.003 & 0.005 & 0.001 & -0.002 & 0.021 & 0.044 & 0.006 \\
INADJ_LRVTB & 0.001 & -0.091 & -0.042 & -0.018 & -0.087 & 0.004 & -0.034 & 0.003 & 0.024 & -0.020 & -0.063 & 0.037 \\
\hline
\end{tabular}

Table 3 Time serial relationship between idiosyncratic risk and institutional ownership

\begin{tabular}{lccccccccccc}
\hline \hline Year & 2001 & 2002 & 2003 & 2004 & 2005 & 2006 & 2007 & 2008 & 2009 & 2010 & Total \\
\hline IDIO & 0.055 & 0.046 & 0.057 & 0.084 & 0.102 & 0.132 & 0.223 & 0.182 & 0.143 & 0.109 & 0.118 \\
FUNDHLD & 0.008 & 0.027 & 0.022 & 0.021 & 0.027 & 0.037 & 0.086 & 0.082 & 0.059 & 0.065 & 0.040 \\
SSHLD & 0.012 & 0.017 & 0.014 & 0.010 & 0.008 & 0.006 & 0.005 & 0.003 & 0.003 & 0.003 & 0.007 \\
\hline \hline
\end{tabular}




\section{Table 4 Summary statistics and distributions}

This table reports sample data descriptive statistics and distributions for the period 2001-2010. Panel A reports summary statistics of key variables in the empirical tests. LNMTB is the natural logarithm of market value of equity to book value of total equity ratio. ROA is net operating profit/ book value of total assets. FUNDHLD is the percentage of shares owned by mutual funds. SSHLD is the percentage of shares owned by social security funds. QFIIHLD is the percentage of shares owned by QFIIs. STATEHLD is the percentage of shares owned by state government and if state government is the controlling shareholder in the listed firm. HFINDEX is the ownership concentration measure, the sum of squares of the shareholding percentage of the top five largest shareholders. TANG is the tangibility ratio, defined as tangible assets/ the book value of total assets. LEV is leverage ratio, defined as the ratio of total debts to book value of total assets. SIZE is the natural logarithm of the book value of total assets.

Panel A: Summary statistics

\begin{tabular}{lcccccccc}
\hline \hline variable & $\mathrm{N}$ & mean & $\mathrm{sd}$ & $\mathrm{p} 10$ & $\mathrm{p} 25$ & $\mathrm{p} 50$ & $\mathrm{p} 75$ & $\mathrm{p} 90$ \\
\hline & & & & & & & & \\
LNMTB & 12,852 & 1.045 & 0.776 & 0.164 & 0.528 & 0.994 & 1.492 & 1.985 \\
ROA & 12,852 & 0.056 & 0.090 & -0.014 & 0.024 & 0.052 & 0.090 & 0.136 \\
FUNDHLD & 12,852 & 0.040 & 0.118 & 0.000 & 0.000 & 0.002 & 0.065 & 0.215 \\
QFIIHLD & 12,852 & 0.002 & 0.011 & 0.000 & 0.000 & 0.000 & 0.000 & 0.000 \\
SSHLD & 12,852 & 0.007 & 0.031 & 0.000 & 0.000 & 0.000 & 0.000 & 0.019 \\
STATEHLD & 12,852 & 0.221 & 0.239 & 0.000 & 0.000 & 0.162 & 0.425 & 0.575 \\
TANG & 12,852 & 0.463 & 0.176 & 0.231 & 0.338 & 0.459 & 0.592 & 0.695 \\
LEV & 12,852 & 0.222 & 0.150 & 0.012 & 0.102 & 0.217 & 0.328 & 0.423 \\
SIZE & 12,852 & 21.422 & 1.127 & 20.169 & 20.673 & 21.302 & 22.030 & 22.848 \\
TURNOVER & 12,852 & 0.418 & 0.350 & 0.091 & 0.147 & 0.302 & 0.590 & 0.941 \\
AGE & 12,852 & 8.646 & 4.105 & 3.000 & 5.000 & 8.000 & 12.000 & 14.000 \\
EXRET & 12,852 & 0.117 & 0.618 & -0.403 & -0.175 & -0.006 & 0.257 & 0.811 \\
HFINDEX & 12,852 & 0.199 & 0.136 & 0.052 & 0.093 & 0.165 & 0.281 & 0.397 \\
\hline Pan
\end{tabular}

Panel B: Distribution by year and industry

\begin{tabular}{llll}
\hline Year & No. of firms & \% of total sample & Cumulative \%. \\
\hline 2001 & 1,014 & 7.89 & 7.89 \\
2002 & 1,086 & 8.45 & 16.34 \\
2003 & 1,153 & 8.97 & 25.31 \\
2004 & 1,208 & 9.4 & 34.71 \\
2005 & 1,285 & 10 & 44.71 \\
2006 & 1,282 & 9.98 & 54.68 \\
2007 & 1,342 & 10.44 & 65.13 \\
2008 & 1,445 & 11.24 & 76.37 \\
2009 & 1,513 & 11.77 & 88.14 \\
2010 & 1,524 & 11.86 & 100 \\
Total & 12,852 & 100 & \\
\hline
\end{tabular}


Panel C: Distribution by CRSC industry

\begin{tabular}{llll}
\hline Industry Code & Industry classifications & No. of firms & \% of total sample \\
\hline A & Agriculture, forestry and fishery & 249 & 1.94 \\
B & Mining & 321 & 2.5 \\
C & Manufacturing & 7,216 & 56.15 \\
D & Energy & 618 & 4.81 \\
E & Construction & 246 & 1.91 \\
F & Transport and storage & 499 & 3.88 \\
G & Information Technology & 661 & 5.14 \\
H & Wholesale and retail trade & 928 & 7.22 \\
J & Real estate & 1,088 & 8.47 \\
K & Social service & 405 & 3.15 \\
L & Communication and Cultural Industry & 107 & 0.83 \\
M & Comprehensive & 514 & 4 \\
Total & & 12,852 & 100 \\
\hline \hline
\end{tabular}

\section{Table 5 Correlation matrix}

This table reports correlation table of the data sample for the period 2001-2010. LNMTB is the natural logarithm of market value of equity to book value of total equity ratio. ROA is net operating profit/ book value of total assets. FundHLD is the percentage of shares owned by mutual funds. SSHLD is the percentage of shares owned by social security funds. QFIIHLD is the percentage of shares owned by QFIIs. StateHLD is the percentage of shares owned by state government and if state government is the controlling shareholder in the listed firm. HFINDEX is the ownership concentration measure, the sum of squares of the shareholding percentage of the top five largest shareholders. TANG is the tangibility ratio, defined as tangible assets/ the book value of total assets. LEV is leverage ratio, defined as the ratio of total debts to book value of total assets. SIZE is the natural logarithm of the book value of total assets. EXRET is prior 12-month market-adjusted stock return of a firm and the excess returns are calculated by deducting aggregated-market return from the firm's realized returns.

\begin{tabular}{|c|c|c|c|c|c|c|c|c|c|}
\hline & LNMTB & ROA & FundHLD & QFIIHLD & SSHLD & StateHLD & TANG & LEV & SIZE \\
\hline ROA & $-0.0543 *$ & 1 & & & & & & & \\
\hline FundHLD & $0.1159 *$ & $0.3017^{*}$ & 1 & & & & & & \\
\hline QFIIHLD & 0.0027 & $0.1013^{*}$ & $0.1830 *$ & 1 & & & & & \\
\hline SSHLD & -0.006 & $0.0408^{*}$ & -0.0117 & -0.0176 & 1 & & & & \\
\hline StateHLD & $-0.1917 *$ & $0.0870^{*}$ & $0.1122 *$ & $0.0635^{*}$ & 0.0025 & 1 & & & \\
\hline TANG & $-0.1270 *$ & $0.1199 *$ & 0.0205 & $0.0450 *$ & -0.0041 & $0.1174^{*}$ & 1 & & \\
\hline LEV & $-0.0381 *$ & $-0.2176^{*}$ & $-0.1418 *$ & $-0.0375^{*}$ & $-0.0375^{*}$ & -0.0142 & $0.1971^{*}$ & 1 & \\
\hline SIZE & $-0.3328 *$ & $0.2200^{*}$ & $0.3308^{*}$ & $0.1141 *$ & 0.0169 & $0.3162 *$ & $0.1787^{*}$ & $0.1456^{*}$ & 1 \\
\hline EXRET & $0.3881 *$ & $0.1277^{*}$ & $0.2295^{*}$ & $0.0374 *$ & -0.0188 & -0.0095 & -0.0267 & $-0.0664 *$ & $0.0678 *$ \\
\hline
\end{tabular}




\section{Table 6 Mutual fund ownership and firm performance}

This table reports baseline regressions of the sample for the period 2001-2010. The dependent variables are INADJ_LNMTB, INADJ_ROA and INADJ_NI, respectively. INADJ_LNMTB is the industry-adjusted natural logarithm of market value of equity to book value of total equity ratio. INADJ_ROA is the industry-adjusted net operating profit/ book value of total assets. INADJ_NI is the industry-adjusted net income scaled by book value of equity. FundHLD is the percentage of shares owned by mutual funds. SSHLD is the percentage of shares owned by social security funds. QFIIHLD is the percentage of shares owned by QFIIs. StateHLD is the percentage of shares owned by state government and if state government is the controlling shareholder in the listed firm. HFINDEX is the ownership concentration measure, the sum of squares of the shareholding percentage of the top five largest shareholders. TANG is the tangibility ratio, defined as tangible assets/ the book value of total assets. LEV is leverage ratio, defined as the ratio of total debts to book value of total assets. SIZE is the natural logarithm of the book value of total assets. EXRET is prior 12-month market-adjusted stock return of a firm and the excess returns are calculated by deducting aggregated-market return from the firm's realized returns. The estimations correct the error structure for heteroskedasticity and clustering using the White-Huber estimator. $t$-statistics (reported in parentheses) significant at the $10 \%, 5 \%$, and $1 \%$ levels are designated with $*, * *$, and $* * *$, respectively.

\begin{tabular}{|c|c|c|c|}
\hline VARIABLES & $\begin{array}{c}(1) \\
\text { INADJ_LNMTB }\end{array}$ & $\begin{array}{c}(2) \\
\text { INADJ_ROA }\end{array}$ & $\begin{array}{c}(3) \\
\text { INADJ_NI }\end{array}$ \\
\hline STATEHLD $_{\mathrm{t}-1}$ & $\begin{array}{l}-0.019 \\
(-0.65)\end{array}$ & $\begin{array}{l}-0.001 \\
(0.34)\end{array}$ & $\begin{array}{l}-0.011 \\
(-1.40)\end{array}$ \\
\hline FUNDHLD $_{\mathrm{t}-1}$ & $\begin{array}{c}1.024 * * * \\
(23.32)\end{array}$ & $\begin{array}{c}0.062 * * * \\
(9.86)\end{array}$ & $\begin{array}{c}0.073 * * \\
(2.30)\end{array}$ \\
\hline QFIIHLD $_{\mathrm{t}-1}$ & $\begin{array}{l}1.514 * * * \\
(4.51)\end{array}$ & $\begin{array}{l}0.086 * \\
(1.78)\end{array}$ & $\begin{array}{l}0.163 \\
(0.67)\end{array}$ \\
\hline SSHLD $_{\mathrm{t}-1}$ & $\begin{array}{l}-0.006 \\
(-0.05)\end{array}$ & $\begin{array}{l}0.027 \\
(1.40)\end{array}$ & $\begin{array}{l}0.124 \\
(1.31)\end{array}$ \\
\hline TANG $_{\mathrm{t}}$ & $\begin{array}{c}0.110 * * * \\
(3.37)\end{array}$ & $\begin{array}{l}0.017 * * * \\
(3.52)\end{array}$ & $\begin{array}{l}0.012 \\
(0.50)\end{array}$ \\
\hline $\mathrm{LEV}_{\mathrm{t}}$ & $\begin{array}{c}0.710 * * * \\
(17.27)\end{array}$ & $\begin{array}{c}-0.153 * * * \\
(-25.70)\end{array}$ & $\begin{array}{c}-0.657 * * * \\
(-22.16)\end{array}$ \\
\hline $\mathrm{SIZE}_{\mathrm{t}}$ & $\begin{array}{c}-0.443 * * * \\
(-43.37)\end{array}$ & $\begin{array}{c}0.009 * * * \\
(5.98)\end{array}$ & $\begin{array}{c}0.103 * * * \\
(13.94)\end{array}$ \\
\hline TURNOVER $_{\mathrm{t}}$ & $\begin{array}{l}-0.024 \\
(-1.33)\end{array}$ & $\begin{array}{l}-0.001 \\
(-0.31)\end{array}$ & $\begin{array}{c}-0.030 * * \\
(-2.34)\end{array}$ \\
\hline $\mathrm{AGE}_{\mathrm{t}}$ & $\begin{array}{c}0.034 * * * \\
(13.20)\end{array}$ & $\begin{array}{c}-0.002 * * * \\
(-4.32)\end{array}$ & $\begin{array}{c}-0.012 * * * \\
(-6.59)\end{array}$ \\
\hline $\mathrm{EXRET}_{\mathrm{t}}$ & $\begin{array}{c}0.299 * * * \\
(45.86)\end{array}$ & $\begin{array}{c}0.013 * * * \\
(13.57)\end{array}$ & $\begin{array}{c}0.050 * * * \\
(10.65)\end{array}$ \\
\hline HFINDEX $_{t}$ & $\begin{array}{c}0.467 * * * \\
(7.53)\end{array}$ & $\begin{array}{c}0.056^{* * * *} \\
(6.20)\end{array}$ & $\begin{array}{c}0.209 * * * \\
(4.67)\end{array}$ \\
\hline Constant & $\begin{array}{c}8.873 * * * \\
(43.11)\end{array}$ & $\begin{array}{c}-0.166^{* * *} \\
(-5.57)\end{array}$ & $\begin{array}{c}-2.033 * * * \\
(-13.71)\end{array}$ \\
\hline Firm fixed effects & Yes & Yes & Yes \\
\hline Time fixed effects & Yes & Yes & Yes \\
\hline Observations & 11,167 & 11,167 & 11,167 \\
\hline R-squared & 0.757 & 0.576 & 0.329 \\
\hline
\end{tabular}




\section{Table 7: Mutual fund ownership and the decomposed valuation components}

This table reports the estimation of the decomposed components of market-to-book ratio on mutual fund ownership for the period 2001-2010. The dependent variables are LRVTB, TSSE and FSE, respectively. The LRVTB component measures the value implied by long-run sector accounting multiples relative to book value; it is used as a proxy for growth opportunities. The TSSE component measures valuation deviations when contemporaneous sector accounting multiples differ from long term sector multiples. This component is used as a measure of overvaluation in industry sectors. The FSE component measures firm-specific deviations from valuations implied by current sector (industry) accounting multiples and are intended to capture the extent to which a firm is mis-valued relative to its contemporaneous industry peers. FundHLD is the percentage of shares owned by mutual funds. SSHLD is the percentage of shares owned by social security funds. QFIIHLD is the percentage of shares owned by QFIIs. StateHLD is the percentage of shares owned by state government and if state government is the controlling shareholder in the listed firm. HFINDEX is the ownership concentration measure, the sum of squares of the shareholding percentage of the top five largest shareholders. TANG is the tangibility ratio, defined as tangible assets/ the book value of total assets. LEV is leverage ratio, defined as the ratio of total debts to book value of total assets. SIZE is the natural logarithm of the book value of total assets. EXRET is prior 12-month market-adjusted stock return of a firm and the excess returns are calculated by deducting aggregated-market return from the firm's realized returns. The estimations correct the error structure for heteroskedasticity and clustering using the White-Huber estimator. $t$-statistics (reported in parentheses) significant at the $10 \%, 5 \%$, and $1 \%$ levels are designated with $* * *$, and $* * *$, respectively.

\begin{tabular}{|c|c|c|c|}
\hline VARIABLES & $\begin{array}{c}(1) \\
\text { INADJLRVTB }\end{array}$ & $\begin{array}{c}(2) \\
\text { INADJTSSE }\end{array}$ & $\begin{array}{c}(3) \\
\text { INADJFSE }\end{array}$ \\
\hline STATEHLD $_{\mathrm{t}-1}$ & $\begin{array}{l}0.006 \\
(0.25)\end{array}$ & $\begin{array}{c}0.057 * * * \\
(4.95)\end{array}$ & $\begin{array}{c}-0.085 * * * \\
(-3.52)\end{array}$ \\
\hline FUNDHLD $_{\mathrm{t}-1}$ & $\begin{array}{c}0.275 * * * \\
(10.54)\end{array}$ & $\begin{array}{c}0.116^{* * * *} \\
(7.21)\end{array}$ & $\begin{array}{c}0.650 * * * \\
(21.25)\end{array}$ \\
\hline QFIIHLD $_{\mathrm{t}-1}$ & $\begin{array}{c}0.455 * * * \\
(2.94)\end{array}$ & $\begin{array}{c}0.814 * * * \\
(6.42)\end{array}$ & $\begin{array}{l}0.196 \\
(0.97)\end{array}$ \\
\hline $\mathrm{SSHLD}_{\mathrm{t}-1}$ & $\begin{array}{l}0.045 \\
(0.60)\end{array}$ & $\begin{array}{l}0.001 \\
(0.03)\end{array}$ & $\begin{array}{l}-0.063 \\
(-0.69)\end{array}$ \\
\hline $\mathrm{TANG}_{\mathrm{t}}$ & $\begin{array}{c}0.084 * * * \\
(2.98)\end{array}$ & $\begin{array}{c}-0.038 * * * \\
(-2.72)\end{array}$ & $\begin{array}{c}0.061^{* *} \\
(2.09)\end{array}$ \\
\hline $\mathrm{LEV}_{\mathrm{t}}$ & $\begin{array}{c}-0.456^{* * *} \\
(-11.00)\end{array}$ & $\begin{array}{c}0.165^{* * * *} \\
(9.31)\end{array}$ & $\begin{array}{c}0.991 * * * \\
(26.89)\end{array}$ \\
\hline SIZE $_{t}$ & $\begin{array}{c}-0.427 * * * \\
(-41.96)\end{array}$ & $\begin{array}{c}0.037 * * * \\
(8.32)\end{array}$ & $\begin{array}{c}-0.051 * * * \\
(-4.89)\end{array}$ \\
\hline TURNOVER $_{t}$ & $\begin{array}{c}0.035 * * \\
(2.57)\end{array}$ & $\begin{array}{c}-0.045 * * * \\
(-6.53)\end{array}$ & $\begin{array}{l}-0.014 \\
(-0.94)\end{array}$ \\
\hline $\mathrm{AGE}_{\mathrm{t}}$ & $\begin{array}{c}0.036 * * * \\
(16.21)\end{array}$ & $\begin{array}{c}-0.007 * * * \\
(-5.91)\end{array}$ & $\begin{array}{l}0.001 \\
(0.61)\end{array}$ \\
\hline EXRET $_{t}$ & $\begin{array}{c}0.086^{* * *} \\
(19.15)\end{array}$ & $\begin{array}{c}0.019 * * * \\
(7.63)\end{array}$ & $\begin{array}{c}0.198 * * * \\
(35.47)\end{array}$ \\
\hline HFINDEX $_{\mathrm{t}}$ & $\begin{array}{c}0.278 * * * \\
(5.59)\end{array}$ & $\begin{array}{l}-0.031 \\
(-1.25)\end{array}$ & $\begin{array}{c}0.220 * * * \\
(4.48)\end{array}$ \\
\hline Constant & $\begin{array}{c}0.779 * * * \\
(42.95)\end{array}$ & $\begin{array}{c}-0.750 * * * \\
(-8.28)\end{array}$ & $\begin{array}{c}0.790 * * * \\
(3.77)\end{array}$ \\
\hline Firm fixed effects & Yes & Yes & Yes \\
\hline Time fixed effects & Yes & Yes & Yes \\
\hline Observations & 11,167 & 11,167 & 11,167 \\
\hline R-squared & 0.800 & 0.306 & 0.691 \\
\hline
\end{tabular}




\section{Table 8. Mutual fund ownership, idiosyncratic volatility and firm specific valuation}

This table reports the estimation of the industry-adjusted firm specific value component FSE on idiosyncratic volatility and mutual fund ownership for the period 2001-2010. The FSE component measures firm-specific deviations from valuations implied by current sector (industry) accounting multiples and are intended to capture the extent to which a firm is mis-valued relative to its contemporaneous industry peers. IDIO is idiosyncratic volatility, the standard deviation of stock return residuals estimated from CAPM regressions for each firm-year daily stock returns. FundHLD is the percentage of shares owned by mutual funds. SSHLD is the percentage of shares owned by social security funds. QFIIHLD is the percentage of shares owned by QFIIs. StateHLD is the percentage of shares owned by state government and if state government is the controlling shareholder in the listed firm. HFINDEX is the ownership concentration measure, the sum of squares of the shareholding percentage of the top five largest shareholders. TANG is the tangibility ratio, defined as tangible assets/ the book value of total assets. LEV is leverage ratio, defined as the ratio of total debts to book value of total assets. SIZE is the natural logarithm of the book value of total assets. EXRET is prior 12-month market-adjusted stock return of a firm and the excess returns are calculated by deducting aggregated-market return from the firm's realized returns. The estimations correct the error structure for heteroskedasticity and clustering using the White-Huber estimator. $t$-statistics (reported in parentheses) significant at the $10 \%, 5 \%$, and $1 \%$ levels are designated with $* * *$, and $* * *$, respectively.

\begin{tabular}{|c|c|c|c|}
\hline VARIABLES & (1) & (2) & (3) \\
\hline $\mathrm{IDIO}_{\mathrm{t}-1}$ & $\begin{array}{c}0.768^{* * *} \\
(11.10)\end{array}$ & $\begin{array}{c}0.771^{* * *} \\
(11.11)\end{array}$ & $\begin{array}{c}0.742^{* * *} \\
(10.33)\end{array}$ \\
\hline FUNDHLD $_{\mathrm{t}-1} * \mathrm{IDIO}_{\mathrm{t}-1}$ & & & $\begin{array}{c}1.749 * * * \\
(2.04)\end{array}$ \\
\hline STATEHLD $_{\mathrm{t}-1}$ & $\begin{array}{c}-0.080^{* * *} \\
(-3.32)\end{array}$ & $\begin{array}{c}-0.080^{* * * *} \\
(-3.33)\end{array}$ & $\begin{array}{c}-0.080^{* * *} \\
(-3.32)\end{array}$ \\
\hline FUNDHLD $_{\mathrm{t}-1}$ & $\begin{array}{c}0.631^{* * *} \\
(20.68)\end{array}$ & $\begin{array}{c}0.628^{* * *} \\
(20.53)\end{array}$ & $\begin{array}{c}0.528 * * * \\
(9.84)\end{array}$ \\
\hline QFIIHLD $_{\mathrm{t}-1}$ & & $\begin{array}{l}0.155 \\
(0.78)\end{array}$ & $\begin{array}{l}0.162 \\
(0.82)\end{array}$ \\
\hline SSHLD $_{t-1}$ & & $\begin{array}{l}-0.113 \\
(-1.23)\end{array}$ & $\begin{array}{l}-0.106 \\
(-1.15)\end{array}$ \\
\hline TANG $_{\mathrm{t}}$ & $\begin{array}{c}0.057 * * \\
(1.98)\end{array}$ & $\begin{array}{c}0.058^{* *} \\
(2.00)\end{array}$ & $\begin{array}{c}0.059^{* *} \\
(2.05)\end{array}$ \\
\hline $\mathrm{LEV}_{\mathrm{t}}$ & $\begin{array}{c}0.982 * * * \\
(26.75)\end{array}$ & $\begin{array}{c}0.981 * * * \\
(26.71)\end{array}$ & $\begin{array}{c}0.982 * * * \\
(26.74)\end{array}$ \\
\hline $\mathrm{SIZE}_{\mathrm{t}}$ & $\begin{array}{c}-0.044 * * * \\
(-4.29)\end{array}$ & $\begin{array}{c}-0.044^{* * * *} \\
(-4.30)\end{array}$ & $\begin{array}{c}-0.046^{* * *} \\
(-4.45)\end{array}$ \\
\hline TURNOVER $_{\mathrm{t}}$ & $\begin{array}{c}-0.031 * * \\
(-2.03)\end{array}$ & $\begin{array}{c}-0.031 * * \\
(-2.03)\end{array}$ & $\begin{array}{l}-0.028^{*} \\
(-1.83)\end{array}$ \\
\hline $\mathrm{AGE}_{\mathrm{t}}$ & $\begin{array}{c}-0.007 * * * \\
(-3.02)\end{array}$ & $\begin{array}{c}-0.007 * * * \\
(-3.07)\end{array}$ & $\begin{array}{c}-0.007 * * * \\
(-2.91)\end{array}$ \\
\hline EXRET $_{t}$ & $\begin{array}{c}0.204 * * * \\
(36.95)\end{array}$ & $\begin{array}{c}0.204 * * * \\
(36.89)\end{array}$ & $\begin{array}{c}0.205^{* * *} \\
(36.79)\end{array}$ \\
\hline HFINDEX $_{t}$ & $\begin{array}{c}0.229 * * * \\
(4.66)\end{array}$ & $\begin{array}{c}0.232 * * * \\
(4.71)\end{array}$ & $\begin{array}{c}0.231^{* * *} \\
(4.69)\end{array}$ \\
\hline Constant & $\begin{array}{c}0.653 * * * \\
(3.15)\end{array}$ & $\begin{array}{c}0.656^{* * *} \\
(3.16)\end{array}$ & $\begin{array}{c}0.699 * * * \\
(3.33)\end{array}$ \\
\hline Firm fixed effects & Yes & Yes & Yes \\
\hline Time fixed effects & Yes & Yes & Yes \\
\hline Observations & 11,167 & 11,167 & 11,167 \\
\hline R-squared & 0.696 & 0.696 & 0.697 \\
\hline
\end{tabular}




\section{Table 9. Changes in number of mutual funds and changes in mutual fund ownership}

This table reports the estimation of the firm specific value component FSE on two measures of mutual fund holdings: average annual changes in fund ownership (CHGFUNDHLD) and average annual changes in the number of mutual funds holding a stock (CHGFUNDNUM) for the period 2001-2010. The FSE component measures firm-specific deviations from valuations implied by current sector (industry) accounting multiples and are intended to capture the extent to which a firm is misvalued relative to its contemporaneous industry peers. IDIO is idiosyncratic volatility, the standard deviation of stock return residuals estimated from CAPM regressions for each firm-year daily stock returns. FundHLD is the percentage of shares owned by mutual funds. SSHLD is the percentage of shares owned by social security funds. QFIIHLD is the percentage of shares owned by QFIIs. StateHLD is the percentage of shares owned by state government and if state government is the controlling shareholder in the listed firm. HFINDEX is the ownership concentration measure, the sum of squares of the shareholding percentage of the top five largest shareholders. TANG is the tangibility ratio, defined as tangible assets/ the book value of total assets. LEV is leverage ratio, defined as the ratio of total debts to book value of total assets. SIZE is the natural logarithm of the book value of total assets. EXRET is prior 12-month market-adjusted stock return of a firm and the excess returns are calculated by deducting aggregated-market return from the firm's realized returns. The estimations correct the error structure for heteroskedasticity and clustering using the White-Huber estimator. $t$-statistics (reported in parentheses) significant at the 10\%, 5\%, and $1 \%$ levels are designated with $*, * *$, and $* * *$, respectively.

\begin{tabular}{|c|c|c|c|c|}
\hline VARIABLES & $\begin{array}{c}(1) \\
\text { OLS }\end{array}$ & $\begin{array}{c}(2) \\
\text { Fixed Effects } \\
\end{array}$ & $\begin{array}{c}(3) \\
\text { OLS }\end{array}$ & $\begin{array}{c}\text { (4) } \\
\text { Fixed Effects } \\
\end{array}$ \\
\hline CHGFUNDHLD $_{\mathrm{t}-1}$ & $\begin{array}{c}0.581 * * * \\
(6.89)\end{array}$ & $\begin{array}{c}0.442 * * * \\
(8.00)\end{array}$ & & \\
\hline CHGFUNDNUM $_{\mathrm{t}-1}$ & & & $\begin{array}{c}0.698 * * * \\
(9.94)\end{array}$ & $\begin{array}{c}0.345^{* * *} * \\
(7.47)\end{array}$ \\
\hline STATEHLD $_{\mathrm{t}-1}$ & $\begin{array}{l}-0.032 \\
(-1.42)\end{array}$ & $\begin{array}{l}-0.034 \\
(-0.70)\end{array}$ & $\begin{array}{l}-0.035 \\
(-1.54)\end{array}$ & $\begin{array}{l}-0.034 \\
(-0.70)\end{array}$ \\
\hline QFIIHLD $_{\mathrm{t}-1}$ & $\begin{array}{c}0.617 * * \\
(2.46)\end{array}$ & $\begin{array}{l}0.247 \\
(1.25)\end{array}$ & $\begin{array}{c}0.583 * * \\
(2.34)\end{array}$ & $\begin{array}{l}0.252 \\
(1.25)\end{array}$ \\
\hline SSHLD $_{\mathrm{t}-1}$ & $\begin{array}{c}0.278 * * * \\
(2.79)\end{array}$ & $\begin{array}{l}-0.040 \\
(-0.39)\end{array}$ & $\begin{array}{c}0.283 * * * \\
(2.81)\end{array}$ & $\begin{array}{l}-0.042 \\
(-0.40)\end{array}$ \\
\hline $\mathrm{TANG}_{\mathrm{t}}$ & $\begin{array}{c}-0.137 * * * \\
(-5.12)\end{array}$ & $\begin{array}{l}-0.005 \\
(-0.14)\end{array}$ & $\begin{array}{c}-0.143 * * * \\
(-5.35)\end{array}$ & $\begin{array}{l}-0.010 \\
(-0.26)\end{array}$ \\
\hline $\mathrm{LEV}_{\mathrm{t}}$ & $\begin{array}{c}0.811 * * * \\
(22.90)\end{array}$ & $\begin{array}{c}0.974 * * * \\
(17.79)\end{array}$ & $\begin{array}{c}0.829 * * * \\
(23.50)\end{array}$ & $\begin{array}{c}0.970 * * * \\
(17.77)\end{array}$ \\
\hline $\operatorname{SIZE}_{\mathrm{t}}$ & $\begin{array}{c}0.034 * * * \\
(6.72)\end{array}$ & $\begin{array}{c}0.042^{* * * *} \\
(2.85)\end{array}$ & $\begin{array}{c}0.028 * * * \\
(5.48)\end{array}$ & $\begin{array}{c}0.038 * * * \\
(2.66)\end{array}$ \\
\hline TURNOVER $_{\mathrm{t}}$ & $\begin{array}{c}-0.148 * * * \\
(-6.67)\end{array}$ & $\begin{array}{c}-0.044 * * \\
(-2.31)\end{array}$ & $\begin{array}{c}-0.156 * * * \\
(-7.15)\end{array}$ & $\begin{array}{c}-0.058 * * * \\
(-3.00)\end{array}$ \\
\hline $\mathrm{AGE}_{\mathrm{t}}$ & $\begin{array}{c}0.003 * * \\
(2.44)\end{array}$ & $\begin{array}{l}0.001 \\
(0.26)\end{array}$ & $\begin{array}{l}0.002 * \\
(1.83)\end{array}$ & $\begin{array}{l}0.004 \\
(0.95)\end{array}$ \\
\hline EXRET $_{\mathrm{t}}$ & $\begin{array}{c}0.211 * * * \\
(25.17)\end{array}$ & $\begin{array}{c}0.169 * * * \\
(26.78)\end{array}$ & $\begin{array}{c}0.208 * * * \\
(25.00)\end{array}$ & $\begin{array}{c}0.168 * * * \\
(26.67)\end{array}$ \\
\hline HFINDEX $_{\mathrm{t}}$ & $\begin{array}{c}0.369 * * * \\
(8.70)\end{array}$ & $\begin{array}{c}0.296^{* * * *} \\
(3.93)\end{array}$ & $\begin{array}{c}0.372 * * * \\
(8.79)\end{array}$ & $\begin{array}{c}0.306^{* * * *} \\
(4.09)\end{array}$ \\
\hline Constant & $\begin{array}{c}-0.931 * * * \\
(-8.19)\end{array}$ & $\begin{array}{c}-1.137 * * * \\
(-3.90)\end{array}$ & $\begin{array}{c}-0.779 * * * \\
(-6.78)\end{array}$ & $\begin{array}{c}-1.097 * * * \\
(-3.79)\end{array}$ \\
\hline Firm fixed effects & No & Yes & No & Yes \\
\hline Time fixed effects & Yes & Yes & Yes & Yes \\
\hline Observations & 6,269 & 6,269 & 6,269 & 6,269 \\
\hline R-squared & 0.227 & 0.737 & 0.235 & 0.736 \\
\hline
\end{tabular}




\section{Table 10. Changes in number of mutual funds, changes in mutual fund ownership and idiosyncratic volatility}

This table reports the estimation of the firm specific value component FSE on idiosyncratic volatility and two measures of mutual fund holdings, namely average annual changes in fund ownership (CHGFUNDHLD) and average annual changes in the number of mutual funds holding a stock (CHGFUNDNUM) for the period 20012010. The FSE component measures firm-specific deviations from valuations implied by current sector (industry) accounting multiples and are intended to capture the extent to which a firm is misvalued relative to its contemporaneous industry peers. IDIO is idiosyncratic volatility, the standard deviation of stock return residuals estimated from CAPM regressions for each firm-year daily stock returns. FundHLD is the percentage of shares owned by mutual funds. SSHLD is the percentage of shares owned by social security funds. QFIIHLD is the percentage of shares owned by QFIIs. StateHLD is the percentage of shares owned by state government and if state government is the controlling shareholder in the listed firm. HFINDEX is the ownership concentration measure, the sum of squares of the shareholding percentage of the top five largest shareholders. TANG is the tangibility ratio, defined as tangible assets/ the book value of total assets. LEV is leverage ratio, defined as the ratio of total debts to book value of total assets. SIZE is the natural logarithm of the book value of total assets. EXRET is prior 12-month market-adjusted stock return of a firm and the excess returns are calculated by deducting aggregated-market return from the firm's realized returns. The estimations correct the error structure for heteroskedasticity and clustering using the White-Huber estimator. $t$-statistics (reported in parentheses) significant at the $10 \%, 5 \%$, and $1 \%$ levels are designated with $* * *$, and $* * *$, respectively.

\begin{tabular}{|c|c|c|c|c|}
\hline VARIABLES & $\begin{array}{c}(1) \\
\text { Fixed Effects }\end{array}$ & $\begin{array}{c}(2) \\
\text { OLS }\end{array}$ & $\begin{array}{c}(3) \\
\text { Fixed Effects }\end{array}$ & $\begin{array}{c}(4) \\
\text { OLS }\end{array}$ \\
\hline $\mathrm{IDIO}_{\mathrm{t}-1}$ & $\begin{array}{c}0.825 * * * \\
(8.67)\end{array}$ & $\begin{array}{c}1.557 * * * \\
(15.30)\end{array}$ & $\begin{array}{c}0.814^{* * * *} \\
(8.55)\end{array}$ & $\begin{array}{c}1.509 * * * \\
(14.82)\end{array}$ \\
\hline CHGFUNDHLD $_{\mathrm{t}-1}$ & $\begin{array}{l}0.047 \\
(0.35)\end{array}$ & $\begin{array}{l}-0.013 \\
(-0.07)\end{array}$ & & \\
\hline CHGFUNDHLD $_{\mathrm{t}-1} *$ IDIO $_{\mathrm{t}-1}$ & $\begin{array}{c}2.380 * * * \\
(2.70)\end{array}$ & $\begin{array}{c}3.224 * * \\
(2.55)\end{array}$ & & \\
\hline CHGFUNDNUM $_{\mathrm{t}-1}$ & & & $\begin{array}{l}-0.011 \\
(-0.13)\end{array}$ & $\begin{array}{c}0.253 * * \\
(2.03)\end{array}$ \\
\hline $\mathrm{CHGFUNDNUM}_{\mathrm{t}-1} * \mathrm{IDIO}_{\mathrm{t}-1}$ & & & $\begin{array}{c}2.836^{* * *} \\
(3.91)\end{array}$ & $\begin{array}{c}3.051 * * * \\
(2.86)\end{array}$ \\
\hline STATEHLD $_{\mathrm{t}-1}$ & $\begin{array}{l}-0.019 \\
(-0.40)\end{array}$ & $\begin{array}{l}-0.030 \\
(-1.35)\end{array}$ & $\begin{array}{l}-0.021 \\
(-0.44)\end{array}$ & $\begin{array}{l}-0.034 \\
(-1.51)\end{array}$ \\
\hline QFIIHLD $_{\mathrm{t}-1}$ & $\begin{array}{l}0.190 \\
(0.97)\end{array}$ & $\begin{array}{c}0.517 * * \\
(2.08)\end{array}$ & $\begin{array}{l}0.209 \\
(1.05)\end{array}$ & $\begin{array}{c}0.507 * * \\
(2.05)\end{array}$ \\
\hline SSHLD $_{\mathrm{t}-1}$ & $\begin{array}{l}-0.096 \\
(-0.90)\end{array}$ & $\begin{array}{l}0.136 \\
(1.37)\end{array}$ & $\begin{array}{l}-0.094 \\
(-0.87)\end{array}$ & $\begin{array}{l}0.144 \\
(1.45)\end{array}$ \\
\hline $\mathrm{TANG}_{\mathrm{t}}$ & $\begin{array}{l}0.002 \\
(0.06)\end{array}$ & $\begin{array}{c}-0.100 * * * \\
(-3.80)\end{array}$ & $\begin{array}{l}-0.001 \\
(-0.03)\end{array}$ & $\begin{array}{c}-0.105 * * * \\
(-4.03)\end{array}$ \\
\hline $\mathrm{LEV}_{\mathrm{t}}$ & $\begin{array}{c}0.981 * * * \\
(17.95)\end{array}$ & $\begin{array}{c}0.752 * * * \\
(21.62)\end{array}$ & $\begin{array}{c}0.980 * * * \\
(17.98)\end{array}$ & $\begin{array}{c}0.769 * * * \\
(22.19)\end{array}$ \\
\hline $\mathrm{SIZE}_{\mathrm{t}}$ & $\begin{array}{c}0.038 * * * \\
(2.63)\end{array}$ & $\begin{array}{c}0.054 * * * \\
(10.53)\end{array}$ & $\begin{array}{c}0.035^{* *} \\
(2.47)\end{array}$ & $\begin{array}{c}0.049 * * * \\
(9.31)\end{array}$ \\
\hline TURNOVER $_{\mathrm{t}}$ & $\begin{array}{c}-0.056^{* * *} \\
(-2.87)\end{array}$ & $\begin{array}{c}-0.204 * * * \\
(-9.04)\end{array}$ & $\begin{array}{c}-0.065^{* * *} \\
(-3.32)\end{array}$ & $\begin{array}{c}-0.207 * * * \\
(-9.32)\end{array}$ \\
\hline $\mathrm{AGE}_{\mathrm{t}}$ & $\begin{array}{c}-0.010 * * \\
(-2.53)\end{array}$ & $\begin{array}{l}0.002 \\
(1.56)\end{array}$ & $\begin{array}{c}-0.008 * * \\
(-2.15)\end{array}$ & $\begin{array}{l}0.001 \\
(1.02)\end{array}$ \\
\hline $\mathrm{EXRET}_{\mathrm{t}}$ & $\begin{array}{c}0.176^{* * * *} \\
(27.78)\end{array}$ & $\begin{array}{c}0.211 * * * \\
(25.66)\end{array}$ & $\begin{array}{c}0.175 * * * \\
(27.78)\end{array}$ & $\begin{array}{c}0.209 * * * \\
(25.57)\end{array}$ \\
\hline HFINDEX $_{t}$ & $\begin{array}{c}0.276^{* * * *} \\
(3.67)\end{array}$ & $\begin{array}{c}0.340 * * * \\
(8.03)\end{array}$ & $\begin{array}{c}0.282 * * * \\
(3.76)\end{array}$ & $\begin{array}{c}0.343^{* * *} * \\
(8.13)\end{array}$ \\
\hline
\end{tabular}




\begin{tabular}{lcccc} 
Constant & $-1.039^{* * *}$ & $-1.517^{* * *}$ & $-0.994^{* * *}$ & $-1.378^{* * *}$ \\
& $(-3.60)$ & $(-13.02)$ & $(-3.48)$ & $(-11.63)$ \\
Firm fixed effects & Yes & No & Yes & No \\
Time fixed effects & Yes & Yes & Yes & Yes \\
Observations & 6,269 & 6,269 & 6,269 & 6,269 \\
R-squared & 0.743 & 0.263 & 0.743 & 0.269 \\
\hline
\end{tabular}

\section{Table 11. Mutual fund ownership, firm specific valuation and Split share reform}

This table reports the estimation of the firm specific value component FSE on idiosyncratic volatility and mutual fund ownership interacting with post split-share-structure reform dummy variable for the period 2001-2010. The FSE component measures firm-specific deviations from valuations implied by current sector (industry) accounting multiples and are intended to capture the extent to which a firm is misvalued relative to its contemporaneous industry peers. IDIO is idiosyncratic volatility, the standard deviation of stock return residuals estimated from CAPM regressions for each firm-year daily stock returns. FundHLD is the percentage of shares owned by mutual funds. SSHLD is the percentage of shares owned by social security funds. QFIIHLD is the percentage of shares owned by QFIIs. StateHLD is the percentage of shares owned by state government and if state government is the controlling shareholder in the listed firm. HFINDEX is the ownership concentration measure, the sum of squares of the shareholding percentage of the top five largest shareholders. TANG is the tangibility ratio, defined as tangible assets/ the book value of total assets. LEV is leverage ratio, defined as the ratio of total debts to book value of total assets. SIZE is the natural logarithm of the book value of total assets. EXRET is prior 12-month market-adjusted stock return of a firm and the excess returns are calculated by deducting aggregated-market return from the firm's realized returns. The estimations correct the error structure for heteroskedasticity and clustering using the White-Huber estimator. $t$-statistics (reported in parentheses) significant at the $10 \%, 5 \%$, and $1 \%$ levels are designated with $* * *$, and $* * *$, respectively.

\begin{tabular}{|c|c|c|c|}
\hline & (1) & (2) & (3) \\
\hline Post*FUNDHLD $_{\mathrm{t}-1} * \mathrm{IDIO}_{\mathrm{t}-1}$ & & & $\begin{array}{c}-3.953 * * * \\
(-4.63)\end{array}$ \\
\hline Post*FUNDHLD $_{\mathrm{t}-1}$ & $\begin{array}{c}0.173 * * * \\
(3.84)\end{array}$ & & $\begin{array}{c}0.689 * * * \\
(5.74)\end{array}$ \\
\hline Post $^{* *} \mathrm{IDIO}_{\mathrm{t}-1}$ & & $\begin{array}{l}0.078 \\
(0.63)\end{array}$ & $\begin{array}{c}0.322 * * \\
(2.37)\end{array}$ \\
\hline $\mathrm{IDIO}_{\mathrm{t}-1}$ & $\begin{array}{c}0.793 * * * \\
(11.30)\end{array}$ & $\begin{array}{c}0.722 * * * \\
(6.80)\end{array}$ & $\begin{array}{c}0.603 * * * \\
(5.33)\end{array}$ \\
\hline FUNDHLD $_{\mathrm{t}-1} * \mathrm{IDIO}_{\mathrm{t}-1}$ & & & $\begin{array}{c}2.408 * * * \\
(3.71)\end{array}$ \\
\hline STATEHLD $_{\mathrm{t}-1}$ & $\begin{array}{c}-0.079 * * * \\
(-3.29)\end{array}$ & $\begin{array}{c}-0.080 * * * \\
(-3.33)\end{array}$ & $\begin{array}{c}-0.077 * * * \\
(-3.23)\end{array}$ \\
\hline FUNDHLD $_{\mathrm{t}-1}$ & $\begin{array}{c}0.547 * * * \\
(15.58)\end{array}$ & $\begin{array}{c}0.628 * * * \\
(20.52)\end{array}$ & $\begin{array}{c}0.309 * * * \\
(4.37)\end{array}$ \\
\hline QFIIHLD $_{\mathrm{t}-1}$ & $\begin{array}{l}0.216 \\
(1.09)\end{array}$ & $\begin{array}{l}0.150 \\
(0.76)\end{array}$ & $\begin{array}{l}0.181 \\
(0.91)\end{array}$ \\
\hline SSHLD $_{\mathrm{t}-1}$ & $\begin{array}{l}-0.098 \\
(-1.06)\end{array}$ & $\begin{array}{l}-0.113 \\
(-1.23)\end{array}$ & $\begin{array}{l}-0.081 \\
(-0.88)\end{array}$ \\
\hline $\mathrm{TANG}_{\mathrm{t}}$ & $\begin{array}{c}0.061 * * \\
(2.12)\end{array}$ & $\begin{array}{c}0.057 * * \\
(1.98)\end{array}$ & $\begin{array}{c}0.061 * * \\
(2.12)\end{array}$ \\
\hline $\mathrm{LEV}_{\mathrm{t}}$ & $\begin{array}{c}0.987 * * * \\
(26.82)\end{array}$ & $\begin{array}{c}0.982 * * * \\
(26.71)\end{array}$ & $\begin{array}{c}0.992 * * * \\
(26.94)\end{array}$ \\
\hline
\end{tabular}




\begin{tabular}{lccc} 
SIZE $_{\mathrm{t}}$ & $-0.050^{* * *}$ & $-0.044^{* * *}$ & $-0.052^{* * *}$ \\
& $(-4.70)$ & $(-4.29)$ & $(-4.88)$ \\
TURNOVER $_{\mathrm{t}}$ & $-0.031^{* *}$ & $-0.032^{* *}$ & -0.023 \\
& $(-2.01)$ & $(-2.05)$ & $(-1.44)$ \\
AGE $_{\mathrm{t}}$ & $-0.008^{* * *}$ & $-0.008^{* * *}$ & $-0.013^{* * *}$ \\
& $(-3.39)$ & $(-3.05)$ & $(-4.49)$ \\
EXRET $_{\mathrm{t}}$ & $0.206^{* * *}$ & $0.204^{* * *}$ & $0.208^{* * *}$ \\
& $(36.93)$ & $(36.89)$ & $(36.90)$ \\
HFINDEX $_{\mathrm{t}}$ & $0.238^{* * *}$ & $0.232^{* * *}$ & $0.240^{* * *}$ \\
& $(4.83)$ & $(4.71)$ & $(4.89)$ \\
Constant & $0.767^{* * *}$ & $0.663^{* * *}$ & $0.842^{* * *}$ \\
& $(3.60)$ & $(3.19)$ & $(3.94)$ \\
& & & \\
Firm fixed effects & Yes & Yes & Yes \\
Time fixed effects & Yes & Yes & Yes \\
Observations & 11,167 & 11,167 & 11,167 \\
R-squared & 0.697 & 0.696 & 0.698 \\
\hline
\end{tabular}

\section{Table 12. Mutual fund ownership, firm specific valuation and Split share reform}

This table illustrates the effects of interaction terms on the firm specific value component FSE for four representative samples reported in Table11. Specifically, low mutual fund ownership firms are firms at the 25th percentile of FUNDHLD (with a value of $0 \%$ ) and high mutual fund ownership firms are firms at the 75th percentile of FUNDHLD (with a value of 5.9\%) in the sample. Low idiosyncratic volatility firms are firms at the 25th percentile of IDIO (with a value of 0.0567 ) and high idiosyncratic volatility firms are firms at the 75th percentile of IDIO (with a value of 0.1648) in the sample. The FSE component measures firm-specific deviations from valuations implied by current sector (industry). HF-LF is High mutual fund ownership firms minus Low mutual fund ownership firms. HI-LI is High idiosyncratic volatility firms minus Low idiosyncratic volatility firms.

\section{Before the reform with Post $=0$}

Mutual fund ownership

Idiosyncratic Low High HF-LF

volatility

$\begin{array}{llll}\text { Low } & 0.0342 & 0.0605 & 0.0263 \\ \text { High } & 0.0994 & 0.1410 & 0.0416 \\ \text { HI-LI } & 0.0652 & 0.0805 & \end{array}$

\section{After the reform with Post=1}

Mutual fund ownership

\begin{tabular}{llccc}
$\begin{array}{l}\text { Idiosyncratic } \\
\text { volatility }\end{array}$ & & Low & High & HF-LF \\
& Low & 0.0524 & 0.1061 & 0.0537 \\
& High & 0.1524 & 0.1963 & 0.0439 \\
& HI-LI & 0.1000 & 0.0901 & \\
\hline
\end{tabular}

